\title{
AZ ÉRZELEM ÉS A STRATÉGIAI KOMMUNIKÁCIÓ: AZ ÉRZELEM HATÁSA A SZÓBELI KÉRÉSEK MEGFOGALMAZÁSÁRA ÉS ÉRTELMEZÉSÉRE*
}

\author{
FORGÁCS JÓZSEF
}

University of New South Wales, Sydney, Ausztrália

E-mail: j.forgas@unsw.edu.au

\begin{abstract}
A mindennapi nyelvhasználat bonyolult stratégiai választásokat kínál számunkra. Mi a hangulat szerepe abban, ahogyan a szóbeli üzeneteket (pl. kérések) használjuk vagy ahogyan azokra reagálunk? Az Erzelem-befolyás modell (Affect Infusion Model, AIM; FORGAS, 1995a) alapján ez a tanulmány számos olyan új keletü kutatást tekint át, melyek arra az eredményre jutottak, hogy a rossz hangulat udvariasabb, míg a jó hangulat kevésbé udvarias szívességkérési stratégiákat eredményez; valamint, hogy a hangulati állapotok ezen hatásai felerösödnek, ha olyan környezeti tényezök vannak jelen, melyek mélyebb feldolgozást tesznek szükségessé. Az Első vizsgálatban a szomorú kísérleti személyek inkább részesitették elönyben az udvariasabb kéréseket, mint a boldog kísérleti személyek; a Második vizsgálat eredményei szerint a szituációs nehézségek kihangsúlyozzák a hangulat hatását. A Harmadik vizsgálat kimutatta, hogy a hangulat hatása számos, különbözö módon közölt kérés esetén fennáll, és legfeltünöbb a szokatlan, udvariatlan kérések esetén. Egy jól kidolgozott eljárással a Negyedik vizsgálat arra a megállapitásra jutott, hogy a szomorú kisérleti személyek udvariasabbak és határozatlanabbak voltak, amikor egy valóságos párbeszédben, természetes módon kértek szívességet; és jobban is emlékeztek a jól feldolgozott, szokatlan kérésekre. Az Ötödik vizsgálatban a rossz hangulat negatívabb értékelést eredményezett, és csökkentette a kisérleti személyek hajlandóságát arra, hogy szívességeket teljesitsenek; ez a hatás felerösödött a közvetlen és szokatlan kérések esetében. A Hatodik vizsgálat az elöbb említett eredményeket kapta, valamint kimutatta, hogy a kísérleti személyek jobban emlékeztek a szokatlan és udvariatlan kérésekre, ami egybevág azzal a feltevéssel, hogy ezeket az üzeneteket jobban dolgozzák fel. Ezek az eredmények megfelelnek az AIM modelljének, és azon kognitíu feldolgozási
\end{abstract}

* Ezt a kutatást az Ausztrál Kutatási Tanács (Australian Research Council) Különleges Kutatói Ösztöndíja (Special Investigator Award), valamint a német Alexander von Humbolt Alapítvány kutatói ösztöndíja támogatta. Külön köszönet Stephanie Moylan kiemelkedő segítségéért.

A cikket Galaskó Dénes fordította. 
stratégiák szempontjából tárgyaljuk őket, melyek a hangulat hatását közvetítik a komplex verbális stratégiák (pl. a szívességkérés) felé. Megvitatjuk azt is, hogy eredményeink milyen jelentőséggel bírnak a stratégiai személyközi viselkedésre, valamint a jelenlegi érzelem és kogníciós elméletekre nézve.

A mindennapi társas élet nagymértékben szóbeli kommunikáción alapul. Verbális üzeneteket használunk annak érdekében, hogy a világról egy közös képet alakitsunk ki, hogy énképünk egységes egészét megalkossuk, és hogy személyes céljainkat elérjük (MEAD, 1973; VIGOTSZKIJ, 1967). A kérés igen gyakori dolog, mégis stratégiáját tekintve meglehetösen bonyolult interperszonális feladat. Annak ellenére, hogy a verbális üzenetek a társas érintkezés minden területén megtalálhatók, még mindig nagyon keveset tudunk arról, hogy a beszélö aktuális hangulata miként befolyásolja az olyan komplex szóbeli közlések kivitelezését, mint a kérés. Ez a cikk egy sor olyan új keletü munkát tekint át, melyek a szociális kognícióval és itéletalkotással foglalkozó jelenlegi kutatásokat (BOWER, 1991; CLORE, SCHWARZ, CONWAY, 1994; FIEDLER, 1991; FORGAS, 1995b; 2000) próbálják kiterjeszteni az interperszonális viselkedés területeire azáltal, hogy bizonyítják, hogy az aktuális lelkiállapot jelentösen befolyásolja a stratégiai szóbeli kommunikációt, mint amilyen a szívességkérés. Korábbi kutatásokra (BLUM-KULKA, DANET, GERSHON, 1985; GIBBS, 1983, 1985), valamint jelenlegi érzelem-kogníció elméletekre (BLUM-KULKA, DANET, GERSHON, 1985; GIBBS, 1983, 1985) támaszkodva ezek a tanulmányok azt próbálják kimutatni, hogy az aktuális hangulat jelentös információs torzításhoz vezet mind a kérések megfogalmazásánál, mind a kérésekre való reagálásnál.

A kérés egy gyakori és stratégiailag fontos verbális feladat. Sok egyszerü kérés már eleve megfelel az udvariasság konvencionális normáinak, és automatikusan, szinte gondolkodás nélkül használjuk, illetve teljesitjük öket (GIBBS, 1983; LANGER, BLANK, CHANOWITZ, 1978). Bizonyos esetekben azonban egy kérés bonyolultabb feldolgozást igényel azért, hogy megfelelóen értelmezzük a kérési szituációban eleve meglévö feszültséget (BAVELAS, 1985). Az emberek gyakran keresik egy kérés azon optimális formáját, mellyel maximalizálhatják a teljesités esélyét úgy, hogy maga a kérés nem hágja át a szociális normákat, tehát nem sért meg senkit (FORGAS, 1985; GIBBS, 1983; JORDAN, ROLOFF, 1990). Más szóval a bonyolultabb szituációkban a beszélönek pontosabb feldolgozási stratégiákat kell alkalmazni annak érdekében, hogy jól megbecsülhesse kérésének „frappánsságát”, vagyis egy direkt kérési forma teljesitésének vagy elutasitásának lehetöségét és következményeit. Az új kutatások azt feltételezik, hogy a hangulatnak valószinüleg nagy a szerepe az olyan kérések esetében, melyek nyilt és részletes feldolgozási stratégiákat igényelnek (FIEDLER, 1991; FORGAS, 1994; 1995b; 1998a; b; 1999a; b; SEDIKIDES, 1995).

Kulcsszavak: szociolingvisztika, a nyelv szociálpszichológiája, érzelembefolyásolás, érzelmi befolyás, kérés, hangulat, udvariasság

\section{A KÉRÉS MINT STRATÉGIAI KOMMUNIKÁCIÓ}

A mindennapi társalgás során gyakran használunk kéréseket; ezek központi szerepet játszanak társas viselkedésünk koordinálásában és a társas helyzetek kezelésében. A természetes környezetben végzett kutatások négy fajta kérési típust írtak le: 1) információ szerzésére irányuló; 2) javak megszerzésére irányuló; 3) cselekvést indítványozó; 4) engedélyt kérő (BLum-KulKa, DANET, Gershon, 1985). A kéréseknek meg kell felelni a GRICE (1988) által leírt társalgási posztulátumoknak is, mely szerint a szóbeli üzeneteknek eleget kell tenni a minőség, mennyiség, viszony és a mód maximájának; más szóval az üzenetnek igaznak, informatívnak, 
relevánsnak és egyértelműnek kell lennie. Létezik egy másik fontos, gyakorlati kényszer, melyet figyelembe kell venni a kéréseknél: úgy kell megfogalmazni őket, hogy a résztvevőknek lehetősége legyen megfelelő homlokzat vagy társas személyiség fenntartására (GOFFMAN, 1984; HARRE, 1985). A kommunikáció ezen „stratégiai" aspektusa különösen fontos a kérések esetében, ahol mindig fennáll az elutasítás vagy a másik megsértésének kockázata. Mind a szociálpszichológusok (Jones, 1964; Petty, Schumann, Richman, Strathman, 1993), mind az ethnomethodológusok (GOFFMAN, 1984; HARRE, 1985) úgy gondolják, hogy a stratégiai kommunikáció az emberek számára igen megerőltető és komplex kognitív feladatot jelenthet, különösen akkor, amikor az üzenetek nem felelnek meg a társadalmi normáknak, és eltérnek a megszokott gyakorlattól.

Annak ellenére, hogy tartalmilag és formailag nagyon sokfajta kérés létezik, a legtöbb egy dimenziójával - az udvariasság vagy a direktség szintje - leírható. Az udvariasság alapvetően pragmatikus, normatív fogalom, s a legjobban a stratégiai kommunikációt lehetővé tevő, közösen fenntartott kommunikációs szabályokkal definiálhatjuk (BROWN, LEVINSON, 1987). A direktség fogalma azt mutatja, hogy a kérés szemantikus és szintaktikus kifejezése mennyire közvetlen. Általában (de nem szükségszerűen) az udvariasabb kéréseket indirektebb szemantikai és szintaktikai formában kódoljuk. Bár az udvariasság és a közvetlenség fogalma nem azonos, úgy tűnik, hogy szoros kapcsolatban állnak egymással, így fejtegetésünk során egymás szinonimájaként kezeljük őket. Egy adott kultúra vagy szubkultúra tagjainak általában közös, egyértelmű elképzelése van arról, hogy az egyes kérési formák mennyire udvariasak; és úgy fogalmazzák meg kéréseiket, hogy a közvetlenség azon optimális szintjét érjék el, mely az adott helyzetnek megfelel (BLUMKulka, Danet, Gershon, 1985; Forgas, 1983; Gibbs, 1983; 1985). Ahogy a státuskülönbségek nőnek és a bizalmasság foka csökken, nő a homlokzat fenyegetettségének veszélye, a kommunikáció udvariasabbá és indirektebbé kezd válni. A magas státusú beszélők általában jobban kedvelik a közvetlenebb formulákat, mint az alacsonyabb státusú beszélők, valamint a közvetlen kérések sikerének esélye nagyobb bizalmasabb kapcsolat esetén (JORDAN, ROLOFF, 1990). Az ilyen finom kontextusbeli hatások miatt nincs általános lineáris összefüggés a kérés közvetlensége és az eredményesség között. Ez a tény a kérések megfogalmazását még bonyolultabb feladattá teszi, mint ahogy ezt a nyelv pragmatikus aspektusának vizsgálata mostanában feltételezi (FORGAS, 1985; HERRMANN, 1983).

Számos bizonyíték utal arra, hogy bár sok mindennapi beszélgetést odafigyelés nélkül dolgozunk fel (LANGER, BLANK, CHANOWITZ, 1978), néhány kérés komplexebb és kifinomultabb kognitív stratégiát igényel olyankor, amikor a beszélő próbálja értelmezni és megbecsülni üzenete sikerességének várható feltételeit (HERRMANN, 1983; JORDAN, ROLOFF, 1990; VAN DijK, 1985). Az udvariasság szabályainak megtanulása és helyes alkalmazása komplex és nehéz kognitív feladat, mint ahogy ezt fejlődéslélektani kutatások is mutatják (AXIA, BARONI, 1985). Valószínű, hogy minél szokatlanabb és komplexebb egy kérési szituáció, annál rendszerezettebben és alaposabban dolgozzuk fel azt, annál valószínúbb, hogy a hangulat befolyásolja ezt a feldolgozást, és később annál pontosabban fogunk a helyzetre emlékezni (GIBBS, 1985; KiTAYAMA, BuRNSTEIn, 1988). 


\section{HANGULATI HATÁSOK A KÉRÉSEKNÉL}

Hogyan befolyásolja az aktuális lelkiállapot azt, ahogy egy személy megfogalmaz egy kérést, illetve azt, ahogyan reagál egy hozzá intézett kérésre? Annak ellenére, hogy évszázadok óta csodálják az érzelem gondolkodásra és viselkedésre gyakorolt hatását, az ezen a területen végzett pszichológiai kutatások rövid múltra tekintenek vissza. Az érzelmek gondolkodásra gyakorolt hatásának korai magyarázatai vagy pszichoanalitikus fogalmakat használtak, mint például a projekció (FESHBACH, SingER, 1957), vagy behaviorista elméleteket (BERKOWITZ, 1993; CLORE, BYRNE, 1974). Ezzel szemben a jelenlegi elméletek azokra a kognitív mechanizmusokra figyelnek, melyek összekapcsolják az érzelmeket és a gondolkodást (Clore, SCHWARZ, CONWAY, 1994; Forgas, 1992a; 1995a; 2000; in press; Kruglanski, 1989; Martin, 1986; Petty, Gleicher, Baker, 1991; SchWARZ, BLESS, 1991; SINCLAIR, MARK, 1992). Kétfajta kogníciót befolyásoló érzelmi hatást tártak fel: (1) információs hatás, amikor az érzelmek azt befolyásolhatják, hogy mit gondolnak az emberek (a kogníció tartalma), és (2) a feldolgozási hatás, amikor a hangulat azt befolyásolja, hogy hogyan gondolkodnak az emberek (a kognitív feldolgozás). A hangulat információra gyakorolt hatása gyakran közvetett, és különböző emlékezeti mechanizmusokon keresztül múködik, mint például a szelektív bevésődés és a hangulattal megegyező információ nagyobb mértékű felhasználása (BOWER, 1991; BOWER, FORGAS, in press; FORGAS, BOWER, 1987; FORGAS, BOWER, KRANTZ, 1984). A hangulattal megegyező információ jobb hozzáférhetősége és használata a társas helyzetek elfogult megítélését eredményezi, így befolyásolja a kérések megfogalmazását, valamint az azokra való reagálást. A hangulat közvetlen hatást gyakorolhat az emberek ítéleteire, amikor az aktuális hangulati állapotot információként használjuk a „mit érzek ezzel kapcsolatban?” heurisztika alapján (Clore, SCHWARZ, CONWAY, 1994; in press; SCHWARZ, Bless, 1991; SCHWARZ, ClORE, 1983). Annak ellenére, hogy komoly bizonyítékok támasztják alá azt, hogy a stratégiai szóbeli üzenetek konstruktív és generatív jellegúek (BAVElas, 1985; Clark, SCHUnk, 1980; Fiedler, 1991; GibBS, 1983; ForgaS, 1985), itt arra a megállapításra jutunk, hogy a hangulat kérésre gyakorolt hatását valószínűleg az érzelem-bevésődés mechanizmusok közvetítik (BOwER, 1991; FORGAS, 1995a).

Az Érzelem-befolyás modell (AIM, Affect Infusion Model). A hangulat különböző információs és feldolgozási hatásait nemrég egy átfogó feldolgozási modellbe integrálta FORGAS (1992a; 1995a), különböző szerzők, mint például BREWER (1988), Chaiken (1980), Fiedler (1991), Kruglanski (1989), PeTty, Gleicher, BakeR (1991) és még mások feldolgozáson alapuló modelljeit használva fel. A modell szerint az érzelem kognícióra és a viselkedésre gyakorolt befolyásoló hatása egy feldolgozási kontinuum mentén mozog. Ez a modell négy alternatív feldolgozási eljárást ír le két szempont alapján: (a) az emberek információkeresési stratégiája (nyílt vagy célirányos keresés), és (b) az információ teljességének hatása a válaszadásra nézve (teljes vagy részleges keresés). A modell által leírt négy feldolgozási stratégia: (a) közvetlen hozzáférés egy már meglévő válaszhoz, és (b) motivált feldolgo- 
zás egy már létező cél érdekében, vagy a hangulat javítása érdekében. Mindkét stratégia igen közvetlen és célirányos információkeresési módszereket használ, ezzel csökkentve a hangulati hatás befolyását. Például egy meglehetősen szokványos kérést megfogalmazhatunk egyszerű, közvetlen feldolgozási stratégiát használva, így viszonylag függetlenné válik hangulatunktól.

Ezzel szemben azokat a feladatokat, melyek valamelyest konstruktív feldolgozást igényelnek vagy (c) egyszerűsített, illetve heurisztikus feldolgozás, vagy (d) szisztematikus, illetve részletes feldolgozás segítségével hajtjuk végre. Ezek a feldolgozási stratégiák megengedik a hangulat mint befolyásoló tényező jelenlétét, mivel az emberek közvetlenül információként használhatják fel hangulati állapotukat (a heurisztikus feldolgozás esetén), illetve válaszuk megfogalmazásánál a hangulat által meghatározott információt használhatják fel (a részletes feldolgozás alatt). Az Érzelem-befolyás modell szerint a feldolgozási stílus megválasztását olyan tényezők határozzák meg, mint a helyzet összetettsége, félreérthetősége, ismertsége és relevanciája az illető számára, valamint az illető érzelmi állapota, kognitív kapacitása és motivációs szándékai. A modell segítségével a legtöbb olyan empirikus adat magyarázható, ahol megjelenik (vagy éppen hiányzik) a hangulat kognícióra és ítéletekre gyakorolt hatása (FORGAS, 1995a). A modellt számos újabb kutatás is alátámasztja, melyben bizonyították, hogy az ítéletekre gyakorolt hangulati hatás feldolgozásfüggő. Egyértelmű bizonyíték van például arra, hogy minél tovább és alaposabban kell egy személynek egy összetett és szokatlan feladaton gondolkodnia, annál nagyobb annak a valószínűsége, hogy a hangulat hatással lesz a feladat lényegi feldolgozására, s így befolyásolni fogja annak végeredményt (FORGAS, 1992b; 1995b; SEDIKIDES, 1995). A fent említett vizsgálatok alapján ezek a kísérletek azt jósolták, hogy a hangulat hatása szignifikánsan nagyobb azon kérések esetében, melyek bonyolultabb és kínosabb szituációkban hangzanak el, valamint akkor, amikor a kérés szokatlan vagy a konvencióktól eltérő, mivel ezek a körülmények a feldolgozás mélyebb szintjét követelik meg, így nagyobb lehetőség nyílik az érzelmi hatás megjelenésére.

\section{CÉLOK ÉS ELŐREJELZÉSEK}

Annak ellenére, hogy nincs konkrét bizonyíték arra, hogy a hangulat milyen hatást gyakorol a verbális kommunikációra, tudjuk azt, hogy a figyelem, a tanulás, az emlékezet, az asszociációk és az ítéletek során végbemenő bonyolult kognitív folyamatoknál feltűnő a hangulat információs hatása (BOWER, 1991; CLORE, SCHWARZ, CONWAY, 1994; FIEDLER, 1990; FORGAS, 1994, 1998a; c). Az itt bemutatott vizsgálatok túl kívánnak menni a korábbi kutatásokon - melyek az észlelés és az ítéletek területén vizsgálták a hangulat hatását - azáltal, hogy bemutatják, a hangulatnak milyen szerepe van bizonyos társas viselkedésekre, mint például a szóbeli üzenetekre (ARGYLE, 1991). Bizonytalan helyzetekben arra számítunk, hogy az emberek kiterjedtebb és egyénibb feldolgozási stratégiát alkalmaznak. Így az érzelem befolyásoló hatásának fontos szerepet kell játszania mind a kérések megfogalmazásánál, mind az azokra való reagálásnál; különösen a szokatlan és a 
konvencióktól eltérő kérések esetében (FORGAS, 1995a). Az Érzelem-befolyás modell (AIM) szerint a kérések megfogalmazásánál különböző szintű részletes feldolgozási stratégiák működnek akkor, amikor a kommunikátornak konstruktív, nyílt információkeresést kell alkalmaznia, miközben az emlékezetére és a következtetőképességére kell hagyatkoznia annak érdekében, hogy megbecsülhesse szavainak lehetséges következményeit. Ennek értelmében arra számítunk, hogy a vidám és a szomorú kísérleti személyek eltérően ítélik meg kérésük sikerességének esélyeit hangulatuk információs hatásának következtében az részletes feldolgozás során működő érzelem-bevésődési mechanizmusok miatt. A hangulatnak valószínűleg arra is hatása van, ahogy a közvetlen kéréseket értékeljük és válaszolunk rájuk.

A jó hangulatban lévő emberek szelektíven jobban hozzáférnek a pozitív emlékekhez és a hasonló múltbeli tapasztalatokhoz, ezért túlbecsülik kérésük eredményességét, így a kérés teljesítésének esélyét növelendő, megfogalmazásuk közvetlenebb. Ezzel szemben a rossz hangulatban lévő emberek szelektíven olyan eseményeket idéznek fel, amikor túl közvetlen kérések miatt presztízsveszteséget szenvedtek, és ezért inkább óvatosabb, közvetettebb és udvariasabb kérési stratégiát választanak. Mivel a presztízsveszteség szomorú hangulatban rosszabbnak tűnhet, mint jó hangulatban, valószínủ, hogy a rossz hangulatú emberek a másokkal való érintkezés során érzékenyebbek az udvariasság normáira, mint ahogy ezt néhány korábbi kutatás meg is állapította (FORGAS, BOWER, KRANTZ, 1984). Az érzelemi állapot hatása hasonlóan működik abban az esetben is, amikor felénk intézett kéréseket értékelünk és reagálunk rájuk; a negatív hangulatban lévő emberek negatívabb ítéleteket hoznak, és kevésbé teljesítik a kéréseket, különösen akkor, ha az szokatlan.

Ezek a megállapítások nagymértékben egyeznek a korábbi kutatások eredményeivel, melyek azt mutatják, hogy a boldog kísérleti személyek általában magabiztosabbak, ambiciózusabbak, magasabb célokat tűznek ki maguk elé, túlbecsülik a siker valószínűségét, és kisebb kockázatot vállalnak (ISEN, 1987; FORGAS, 1995a; MANN, 1992; SINCLAIR, MARK, 1992). Az az előrejelzésünk, hogy a negatív hangulatban lévő emberek udvariasabban kérnek, szintén összhangban van a korábbi eredményekkel, miszerint a szomorú embereknek rosszabb az önértékelésük (FORGAS, BOWER, KRANTZ, 1984; SEDIKIDES, 1992, 1995), csökken a magabiztosságuk és az énerejük, valamint énleértékelő attitűdöt vesznek fel (FoRGAS, 1994, $1998 \mathrm{a} ; \mathrm{c})$.

\section{Első vizsgálat: \\ A hangulat kérésre gyakorolt hatásának első bemutatása}

Az első vizsgálat célja annak feltárása volt, hogy miként hat a hangulat a kérési stratégiákra. Azt tételeztük fel, hogy az emberek magabiztosabb, közvetlenebb kérési stratégiát használnak pozitív hangulatban, mivel pozitív gondolataikhoz és asszociációikhoz jobban hozzáférnek. Ezzel szemben azok az emberek, akik átmenetileg rossz hangulatban vannak, óvatosabb, udvariasabb kérési stratégiákat választanak, mivel kérésük eredményességét borúlátón ítélik meg. Ezen túl a han- 
gulat hatása valószínűleg erősebben jelentkezik bonyolult és nehéz helyzetben, amikor egyénibb és mélyebb feldolgozási stratégiákra van szükség (FORGAS, 1999a, Exp. 1).

A kísérleti személyek azt hitték, hogy két különálló kísérletben vesznek részt. Az egyik a „társas eseményekre való emlékezést” vizsgálja (valójában ekkor idézték elő a megfelelő hangulatot azzal, hogy vidám vagy szomorú eseményeket kellett felidézni az életükből), a másik a személyközi viselkedést teszteli (ezzel értékelték a kérési stratégiákat). A kísérleti személyek diákok voltak (112fó, férfiak és nők), akik a kísérletben való részvételért kurzuselismerést kaptak. Az ülésről azt mondták, hogy két független kísérletből áll; az egyik a társas eseményekre való emlékezést, a másik az interperszonális viselkedést vizsgálja. Az első feladat részeként (a hangulati állapot indukálása) a kísérleti személyek 10-12 percet kaptak, hogy felidézzenek és leírjanak pozitív, illetve negatív élményeket. Ezután a résztvevők kitöltöttek egy rövid kérdőívet, mely a hangulatindukálás eredményességét vizsgálta.

A második feladatban a kísérleti személyeknek két szituációt mutattak, melyekben könnyebb vagy nehezebb kérési helyzetek voltak, például: „Egy ismerőse kölcsönkért 20 dollárt öntől, és úgy gondolja, hogy talán elfelejtette ezt. Mit mondana, hogy visszakapja pénzét?” A résztvevőket megkérték, hogy öt megfogalmazás közül válasszanak ki egyet; ezek az udvarias és indirekt kérésektől az udvariatlan és direkt kérésekig terjedtek: 1) „Azon gondolkodom, hogy vajon van-e elegendő pénz ma nálam.” 2) „Van nálad egy kis pénz?” 3) „Jól jönne most húsz dollár...” 4) „Azt hiszem, tartozol nekem húsz dollárral.” 5) „Kérlek, add meg a húsz dolláromat!"

A második szituáció nehezebb és kínosabb kérési helyzetet ábrázolt egy vacsorameghívás alatt, ahol a másik megsértésének veszélye nagyobb volt. „Egy barátjánál vacsorázik, aki büszke arra, hogy milyen jól főz. Paradicsomszószt (ketchup) akar kérni az ételéhez, anélkül, hogy megsértse őt. Az alábbi öt lehetőség közül válassza $\mathrm{ki}$ azt a mondatot, melyet a legnagyobb valószínűséggel mondana: 1) Ehhez az ételhez talán még kell valami... 2) Próbáltad már ezt egy kis szósszal? 3) Van ketchupöd? 4) Nincs ketchup az asztalon. 5) Kérek egy kis ketchupöt.” Az elsődleges értékelés $(\mathrm{N}=23)$ azt mutatta, hogy szándékunknak megfelelően a két szituáció nehézségi fokát szignifikánsan különbözőnek ítélték, $\mathrm{t}(21)=8,45$; $\mathrm{M}=3,25$ szemben az 5,18-dal. Mindkét szituáció öt választható kérését elővizsgálattal teszteltük, hogy megállapítsuk, mennyire tartják őket közvetlennek, és úgy találtuk, hogy egy 10 fokozatú skálán a közvetlenség tekintetében körülbelül egyenlő az eloszlásuk (BLUM-KULKA, DANET, GERSHON, 1985; GIBBS, 1985).

A hangulat hatása a kérések meguálasztására. Az eredmények azt mutatták, hogy a hangulat manipulációja igen eredményes volt abban, hogy szignifikánsan különböző jó, illetve rossz lelkiállapotot idézzen elő. Mivel a nemek között nem volt különbség, ezért a nők és férfiak adatait együtt kezeltük. Az összesített varianciaanalízissel - mellyel értékeltük a hangulat hatását (vidám, szomorú), valamint a kérési szituációban (kölcsön- vagy vacsorahelyzet) a kísérleti személyek által választott kérés közvetlenségének fokát - szignifikáns hangulati hatást mutattunk ki. 
A vidám kísérleti személyek jó hangulatban szignifikánsan hajlamosabbak voltak közvetlen és udvariatlan kéréseket választani; míg a szomorú kísérleti személyek inkább a közvetett és udvariasabb kéréseket részesítették előnyben (lásd 1. ábra). A szituáció is szignifikáns befolyásoló hatással bírt, mivel a kísérleti személyek a kellemetlenebb vacsora-helyzetben inkább használtak udvarias kéréseket, mint amikor a kölcsönadott pénzt kérték vissza (legitimebb kérési helyzet). Bár a hangulat hatása valamivel nagyobb volt a nehezebb vacsora-helyzetben, azonban a hangulat és a szituáció kontextusa közötti interakció nem gyakorolt szignifikáns hatást a kérési stratégiákra (1. ábra).

Udvariassági fok

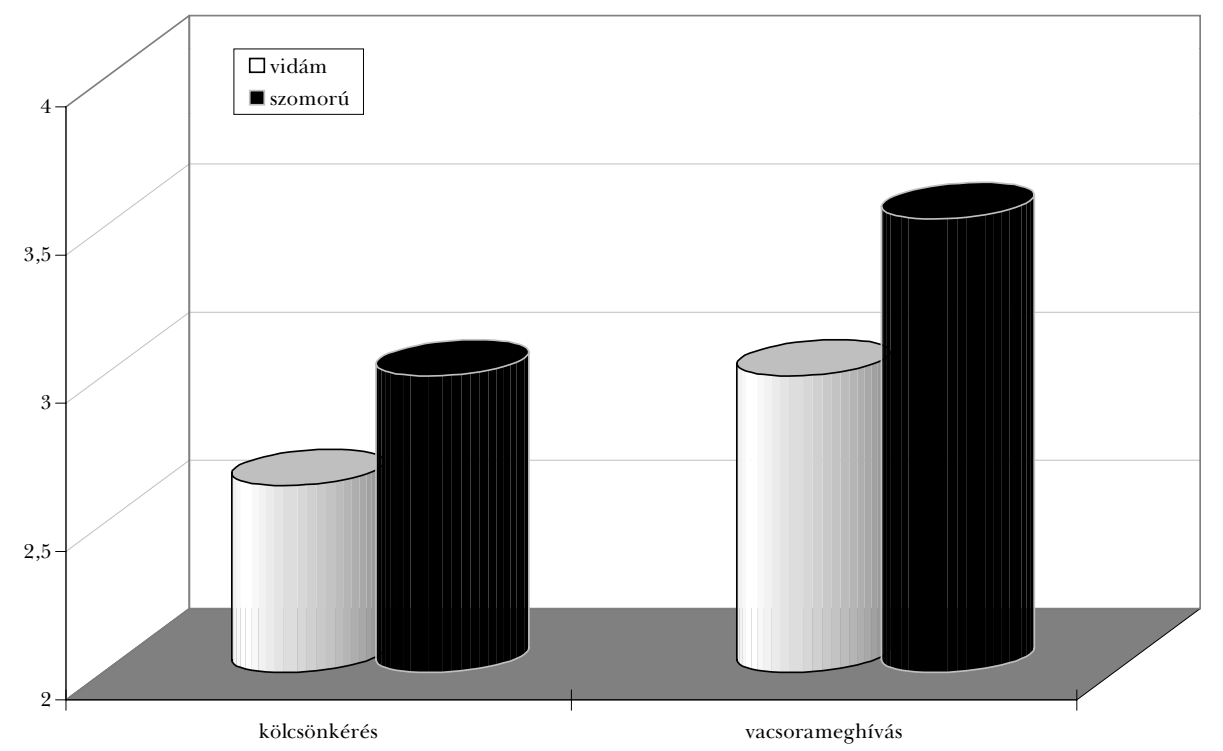

A kérési helyzet

1. ábra. A jó és a rossz hangulat hatása a kérés közvetlenségére (FORGAS, 1999a, Exp. 1)

Az első vizsgálat eredményei azt mutatták, hogy a rövid ideig tartó hangulatnak valóban szignifikáns főhatása lehet a preferált kérési stratégiákra nézve még az olyan viszonylag kevésbé érzékeny mérési eljárás esetén is, mint az itt használt öt előre megfogalmazott kérési lehetőség. Ezek az eredmények biztatóak voltak. Mégis, a hangulat és a szituáció kontextusa közötti megjósolt összefüggés nem volt szignifikáns. A viszonylag érzéketlen mérési módszer (az öt előre megfogalmazott kérés), és az ilyen előre meghatározott választások hatására csökkenő részletes feldolgozás valószínűleg hozzájárult ahhoz, hogy a hangulat és a szituáció közötti interakció elmaradt. A következő vizsgálat célja az volt, hogy jobban feltárja a jelenséget úgy, hogy a kísérleti személy által megfogalmazott kéréseket használ, valamint a kérés minőségét érzékenyebb eszközökkel méri. 


\section{Második vizsgálat: \\ A szituáció nehézsége fokozza a hangulati hatást}

A következő kísérlet megpróbálta megismételni és kiterjeszteni a fent említett eredményeket. Előre megfogalmazott kérések használata helyett a kísérleti személyeket megkérték, hogy fogalmazzák meg és írják le saját szavaikkal a kéréseket, melyeket az egyes szituációkban használnának (ForGAS, 1999a; Exp. 2). A szituációkra adott válaszok ilyen nyílt formája a kérések olyan jellemzőinek elemzését is lehetővé tette, mint a közvetlenség, barátságosság, összetettség, kertelés és kifinomultság, illetve, hogy ezeknek milyen szerepe van a kísérleti személyek hangulatára, valamint a kérési szituációra. Az egyéb jellemzők tekintetében a használt módszerek változatlanok maradtak. A kísérleti személyek $(\mathrm{N}=135)$ azt hitték, hogy két különböző kísérletben vesznek rész, az egyik „a társas eseményekre való emlékezést" vizsgálja (ez az önéletrajzi eseményekkel való hangulatindukálás), a másik a személyközi viselkedés próbája (a kérési stratégiák vizsgálata). A hangulat indukálására ugyanazt az eljárást alkalmaztuk, mint az első kísérlet esetében. A kérési stratégiákat úgy vizsgáltuk, hogy megkértük a kísérleti személyeket: „Írja le szó szerint, hogy fogalmazná meg ezt a kérést!". Minden kérést két bíráló értékelt hat jellemző alapján: a közvetlenség foka, udvariasság, barátságosság, kifinomultság, kertelés és összetettség.

A hangulat és a helyzet nehézségének összefüggése a kéréssel. Az eredmények ismét azt mutatták, hogy a hangulat indukálása igen hatékony volt. A szabadon megfogalmazott kérések főkomponens-elemzése során az összetevőket két faktorba soroltuk: az egyik a kérés udvariassága (melyet az udvarias-udvariatlan, közvetlenközvetett és barátságos-barátságtalan tengely alkot), a másik a kifinomultsága (amit a kifinomult - nem kifinomult, kertelő - nem kertelő és egyszerü - összetett tengely alkot). A hangulat (vidám, szomorú) és a kérési szituáció (kölcsön- vagy vacsorameghívásos helyzet) hatását erre a két függő változóra két szempontú varianciaanalízissel értékeltük. Az eredmények azt mutatták, hogy a hangulatnak szignifikáns hatása van a kérések udvariassági szintjére. A vidám emberek kéréseiket szignifikánsan udvariatlanabbul és közvetlenebb stílusban fogalmazták meg, mint a szomorú személyek (2. ábra). A kérések udvariasabbak voltak a problémásabb vacsorameghívásos helyzetben, mint a kölcsön visszakérésének helyzetében. A hangulat és a szituáció kontextusa, valamint a kérések udvariassági foka között szignifikáns összefüggést találtunk, ami azt mutatja, hogy a hangulat hatása szignifikánsan nagyobb volt a nehezebb vacsorameghívásos helyzetben, mint az egyszerűbb és legitimebb kölcsönvisszakérési helyzetben (2. ábra).

A kérések kifinomultságának, illetve összetettségének elemzése is jelentős hangulati hatást tárt fel. A szomorú kísérleti személyek bonyolultabb és kifinomultabb nyelvi formulákat használtak kérésüknél, mint azok, akik vidámak voltak. A két különböző kérési helyzet nem mutatott fó hatást a kifinomultságra nézve. A hangulat és a helyzet nehézsége között azonban ismét jelentős összefüggés volt. A hangulat szignifikánsan nagyobb hatást gyakorolt a kérés kifinomultságára a bonyolultabb és nehezebb vacsorameghívásos helyzetben, mint a kölcsön visszakérésének helyzetében (2. ábra). 
(a) Udvariassági fok

(b) Kifinomultság

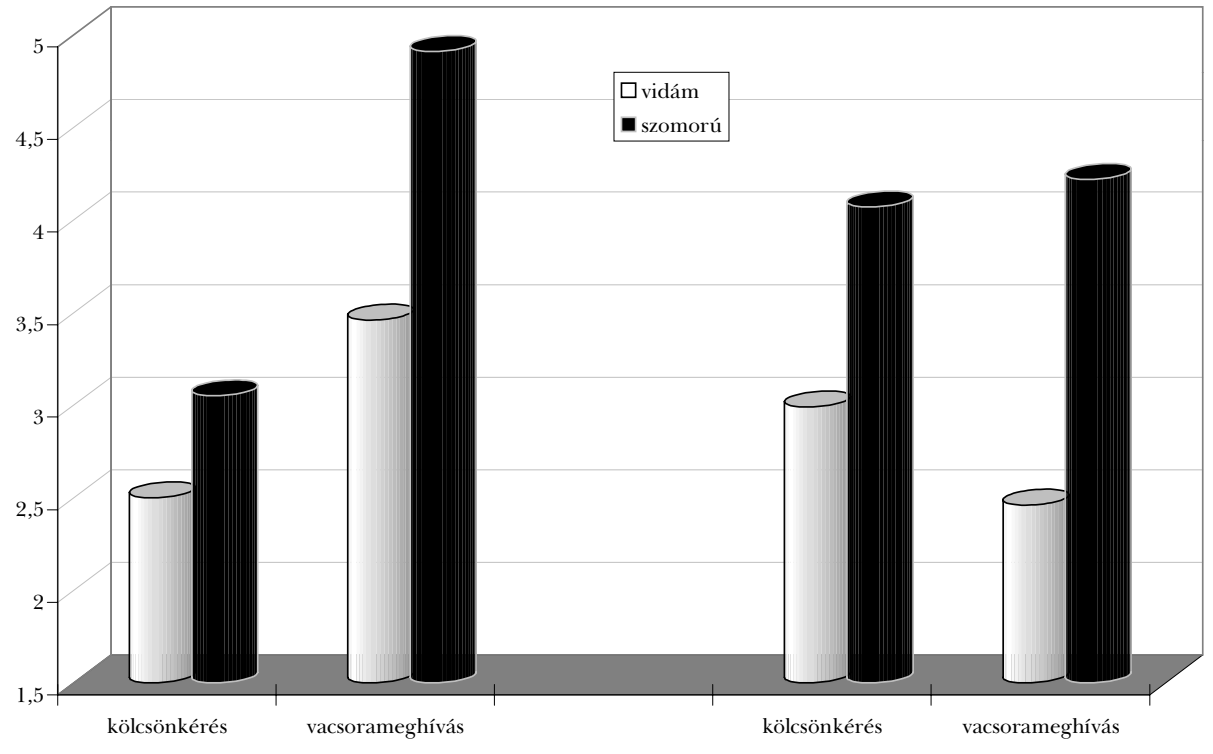

A kérési helyzet

2. ábra. A hangulat hatása a szabadon megfogalmazott kérések (a) udvariasságára és (b) kifinomultságára (FORGAS, 1999a, Exp. 2)

Ezek az eredmények újra azt bizonyítják, hogy a rövid ideig tartó hangulatnak valóban jelentős hatása van a megfogalmazott kérések minősége szempontjából. Úgy találtuk, hogy az itt vizsgált két szituációban a szomorú emberek udvariasabb és kifinomultabb kéréseket fogalmaztak meg. A korábbi vizsgálatok a hangulat hatását csak az emlékezésre és az ítéletekre nézve vizsgálták (BOWER, 1991; Clore, SCHWARz, CONWAY, 1994; Forgas, 1995b; MAYER, HANSON, 1995). Az itt bemutatott vizsgálat ezt a jelenséget kiterjeszti egy teljesen új területre, a stratégiai szóbeli üzenetek megfogalmazásának területére. Különösen érdekes a hangulat és a kérési szituáció, valamint a kérés udvariassági foka és kifinomultságának foka között talált szignifikáns összefüggés (2. ábra). Miért nagyobb a hangulat hatása a vacsorameghívás alkalmával megfogalmazott kérések esetében, mint a kölcsönvisszakérési helyzetben? Ahogy az előtanulmány értékelése is mutatja, a vacsorameghívás helyzete nehezebb feladatot ró a kísérleti személyekre. Egy ilyen feladat valószínűleg kifinomultabb és egyénibb feldolgozási stratégiát igényel. Ezzel szemben egy kölcsön visszafizetését kérni jogosabb (legitimebb) és kevésbé kellemetlen helyzet, amit könnyebb feldolgozni. Az Érzelem-befolyás modell (AIM) szerint az érzelem befolyásoló szerepe akkor nő, amikor a kérés egyénibb feldolgozást igényel, amit a feladat összetettsége és nehézsége határoz meg. Minél problematikusabb és nehezebb a helyzet, annál egyedibb feldolgozás szükséges, és annál nagyobb az esélye annak, hogy az érzelmek által meghatározott asszociációk befolyá- 
solják az eredményt. Az érzelmek befolyásoló hatása miatt a szomorú kísérleti személyek túlbecsülik az elutasítás veszélyét, és ezért udvariasabb formát használnak. Ezzel szemben a vidám kísérleti személyek optimistább és magabiztosabb asszociációkhoz férnek hozzá, így alábecsülik a másik megsértésének veszélyét, aminek következtében - mint ahogy ezt láthattuk is - közvetlenebb kéréseket fogalmaznak meg. A következő vizsgálatban azokat a mechanizmusokat vizsgáltuk, melyek ezekért a hatásokért felelősek.

\section{Harmadik vizsgálat: \\ A kérés szokványosságának szerepe a hangulati hatás közvetítésében}

Az első két vizsgálatból az derült ki, hogy a hangulatnak jelentős hatása van mind az előre megalkotott, mind az önállóan megfogalmazott kérésekre; valamint az, hogy ezek a hatások - mint ahogy ezt az AIM is feltételezi - erősebbek problematikus és bonyolult helyzetekben. A jelenlegi vizsgálat célja bebizonyítani azt, hogy a hangulat kérésre gyakorolt hatása relatíve nagyobb közvetlen és szokatlan kérések esetében, melyek egyénibb feldolgozást igényelnek (GIBBS, 1985; FORGAS, 1995a). Két rövid szituáció helyett a kérési helyzetek szélesebb skáláját vizsgáltuk többfajta lehetséges kérési típussal (javak, információ, cselekvés vagy engedély kérése FORGAS, 1985; JORDAN, ROLOFF, 1990). A korábbi vizsgálatok vagy előre megfogalmazott, vagy nyílt kérési formát alkalmaztak. Itt egy harmadik módszert alkalmaztunk: a kísérleti személyeket megkértük, hogy döntsék el, milyen valószínűséggel használnák a megadott tipikus kérési formákat. Az egyes kérési formákra kapott kedveltségi mutatókat elemeztük, hogy ellenőrizzük hipotézisünket, miszerint a hangulatnak a legközvetlenebb és legszokatlanabb kérések megítélésére van a legnagyobb hatása, melyekről tudjuk, hogy a legegyénibb és legmélyebb feldolgozási stratégiákat mozgósítják (GIBBS, 1983, 1985). Ebben a vizsgálatban, a korábbiaktól eltérően, a hangulatot egy audiovizuális módszerrel manipuláltuk. Egymással összefüggésben lévő kísérletek esetében fontos, hogy különböző hangulatindukálási módszereket használjunk azért, hogy kiküszöböljük az egyéb hangulati hatásokat (FoRGAS, 1994, 1995b). Ezen túl ebben a vizsgálatban kontrollcsoportot is használtunk, hogy felmérjük, milyen hatása van a pozitív és a negatív hangulatnak a különböző kérési stratégiák használatára (FORGAS, 1999b, Exp. 1).

Pozitív, negatív és semleges hangulatot hoztunk létre úgy, hogy megkértük a kísérleti személyeket $(\mathrm{N}=103)$, nézzenek meg rövid jeleneteket videóról. Erről azt mondtuk, hogy nincs kapcsolatban a másik vizsgálatunkkal. A film végén a kísérleti személyek értékelték aktuális lelkiállapotukat egy hétpontos vidámszomorú és jó-rossz skálán. A hangulatindukció után a kísérleti személyeknek el kellett olvasniuk tizenhat rövid szituációt, melyek négyfajta kérési helyzetet szemléltettek: cselekvésre kérés, javak megszerzésére irányuló kérés, információvagy engedélykérést; ezeket vagy egy magasabb, vagy egy alacsonyabb státusban lévő embernek címezték (vö. Blum-KulKa, DANET, GERSHON, 1985; Forgas, 1985). Néhány bemutatott kérési helyzet: „Ön és néhány barátja egy lakást bérel. Meg kell javítani a konyhai szekrény fogantyúit. Felhívja a főbérlőjét, hogy meg- 
kérje, vegyen új fogantyúkat - és ezt mondja - (cselekvésre való kérés)”. „Sorban áll egy áruházban. A sor elején egy gyerek áll. Mivel siet, úgy dönt, megkéri a gyereket, hadd álljon elé a sorba. Ezt mondaná neki - (engedélykérés)." Mind a tizenhat kérési helyzetnél kilenc kérési forma közül lehetett választani, melyek közvetlenségi és udvariassági foka különböző volt. Ezek a mondatok a nyelvileg elfogadható kérések széles körét képviselték; a nagyon direkttől („Csukja be az ablakot!” vagy „Azt akarom, hogy csukja be az ablakot!”) a közepesen át (,Becsukhatná az ablakot.” vagy „Becsukná az ablakot?”) a nagyon indirekt megfogalmazásokig („Hideg van itt.” vagy „Nem bánná, ha becsuknánk az ablakot?”). A kísérleti személyeket megkérték: „...értékelje az itt látható kérési formákat egy hétfokú skálán aszerint, hogy milyen valószínűséggel használná őket. Az 1-es a nagyon valószínűtlen, a 7-es a nagyon valószínű, hogy használnám.”

A hangulat és a kérés udvariassága. A hangulati állapot önbeszámolón alapuló értékelése kimutatta, hogy azok, akik a vidám filmet látták, szignifikánsan jobban érezték magukat, mint a kontrollcsoport, míg akik a szomorú filmet látták, szignifikánsan rosszabbul érezték magukat; ez bizonyította a hangulatindukció eredményességét. A következő lépésben a kilenc kérési alternatívára adott kedveltségi értéket főkomponens-elemzésnek vetettük alá, hogy független, a közvetlenség különböző fokán lévő kéréstípusokat különböztessünk meg. A kéréseket három jól elkülöníthető faktorba lehetett sorolni: (1) a legudvariasabb és legközvetettebb kérések csoportja, melyek utalásokat és kérdéseket használnak (pl.: Hozna esetleg egy krétát? vagy Szeretnék a táblára írni.); (2) közepesen udvarias kérési formák, melyek állításokat tartalmaznak (pl.: Nincs kréta. Szeretnék egy krétát. Hozhatna egy krétát.); és (3) közvetlen és udvariatlan kérések (pl.: Hozz krétát! vagy Azt akarom, hogy hozz krétát!).

A főkomponens-elemzés után azt vizsgáltuk, hogy a hangulatnak (vidám, szomorú, semleges) és a kérési forma udvariasságának (udvarias, közepesen udvarias, udvariatlan) milyen hatása van az egyes formák kedveltségi fokára. Az eredmények szerint a hangulatnak nincs jelentős főhatása a kedveltségi fokra. A kérési típusok esetében azonban kimutatható volt a szignifikáns főhatás. Nem meglepő módon, összességében az udvarias és közepesen udvarias kéréseket szignifikánsan többet választották, mint az udvariatlan kéréseket (3. ábra). Elméletünk szempontjából fontosabb azonban a hangulat és a kérés udvariassága között talált szignifikáns összefüggés, ami azt mutatja, hogy a hangulat nem befolyásolta az udvarias és közepesen udvarias kérések kedveltségét. Az ilyen kérések megfelelnek a hagyományos elvárásoknak, és közvetlenül, odafigyelés nélkül dolgozhatók fel (LANGER, Blank, CHANOWITZ, 1978). „Az emberek sok mindennapi, átvitt értelmű kifejezést az elfogadott nyelvi konvenciók használatával értenek meg” (GIBBS, 1983, 524.), ami azt jelenti, hogy ilyenkor ritka a mélyreható feldolgozás, ennek következtében - az AIM értelmében - az érzelemnek nincs sok tere befolyásoló hatást kifejteni. 
A hangulatnak szignifikáns hatása volt a legközvetlenebb és legudvariatlanabb kérési formák kedveltségére nézve. A közvetlen kéréseket a vidám kísérleti személyeknél kevésbé kedvelték szomorú vagy semleges hangulatú kísérleti személyek (3. ábra). Ez az eredmény megerősíti azt a tényt, hogy a szívességkérésnél a szomorú kísérleti személyek használják legkevésbé a „kockázatos”, közvetlen verbális stratégiákat. Ez hasonló ahhoz a kockázatelkerülő magatartáshoz, amit negatív hangulatban mutatnak mind a normális, mind a depressziós emberek (FORGAS, Bower, Krantz, 1984; OtTAVIANi, Beck, 1988). A vidám emberek viszont szignifikánsan többet használták ezeket a direkt, udvariatlan megfogalmazásokat.

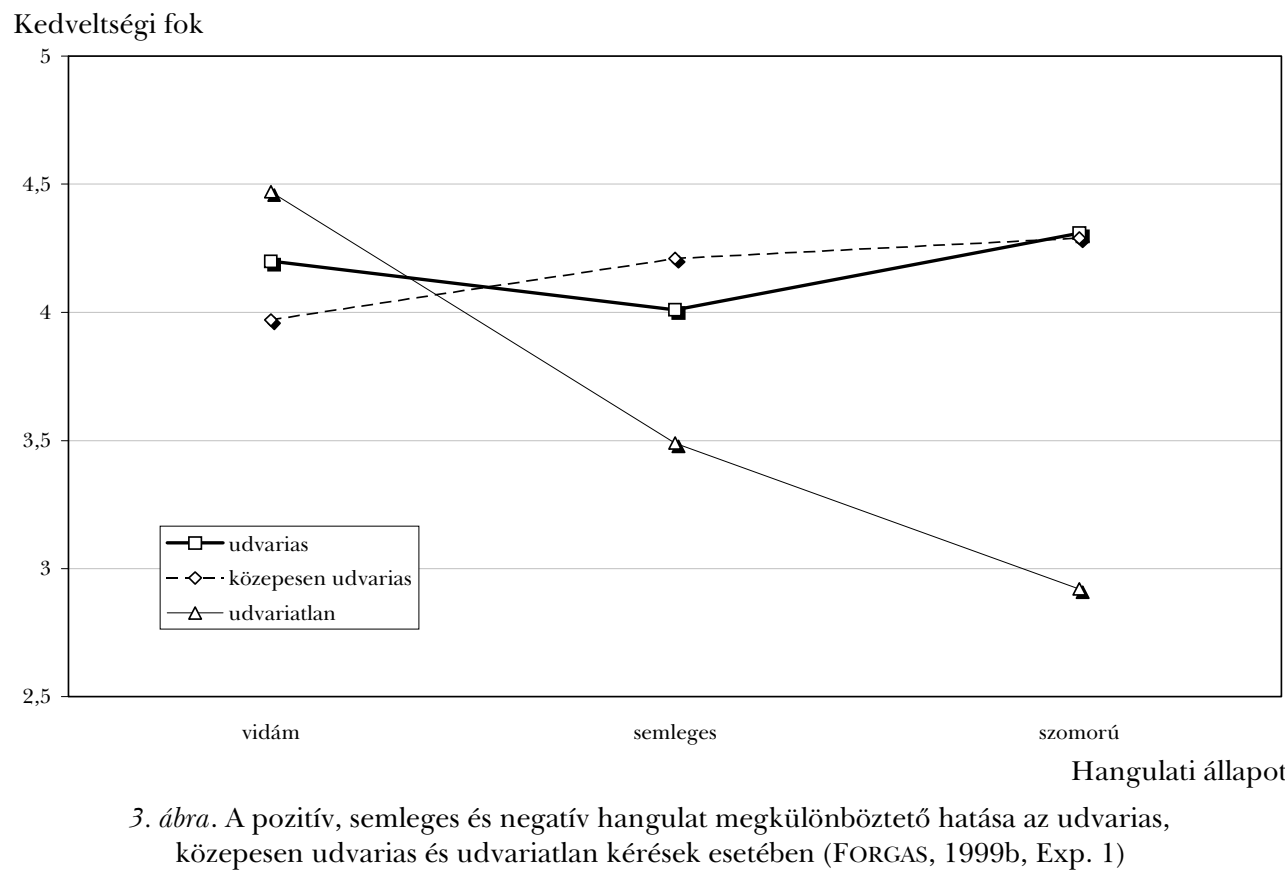

Az eredmények azt mutatják, hogy a hangulat ott befolyásolja legjobban a választott kérési típust, ahol a legnagyobb valószínűséggel szegi meg az udvariasság kulturális normáját, és így alaposabb és kifinomultabb feldolgozási stratégiát igényel (GibBS, 1983). Ehhez hasonlóan, korábbi vizsgálatokból az derül ki, hogy az érzelem hatása ott a legnagyobb, ahol a megítélendő tárgy bonyolult, szokatlan és kétértelmű, ezért hosszabb és alaposabb feldolgozási stratégiát igényel (FIEDLER, 1991; FoRGAS, 1992b, 1994, 1995b; SEDIKIDES, 1995). Az itt bemutatott eredmények alapján a személyközi kommunikációban a hangulat hatása feldolgozásfüggö; az érzelem befolyásoló szerepe akkor a legnagyobb, amikor egy bonyolult kommunikációs feladat konstruktív feldolgozást igényel. 
Bár a fent bemutatott vizsgálatok következetesen és határozottan kimutatták a hangulat kérésekre gyakorolt hatását, ezek mind laboratóriumi körülmények között jöttek létre, ahol a személyek folyamatosan tudatában voltak annak, hogy a kommunikációs stratégiájukat vizsgálják. Mivel az interperszonális kommunikációnkra, különösképpen szóbeli üzeneteinkre nagymértékben odafigyelünk, ezért fontos, hogy vizsgálataink eredményeit természetes körülmények között is megismételjük, ahol a kísérleti személyek nem tudják, hogy a szóbeli közléseiket rögzítik és elemzik. Ez volt következő kísérletünk fő célja. Ez a vizsgálat a spontán kérésekre való emlékezést is vizsgálta. Ha a szokatlan, udvariatlan kérések egyedi feldolgozása valóban növeli a hangulat hatását, akkor később az embereknek jobban kell emlékezniük az ilyen alaposan feldolgozott kérésekre (FORGAS, 1999b; Exp. 2).

A kísérleti személyek ebben a kísérletben is azt hitték, hogy két különböző vizsgálatban vesznek részt, egy audiovizuális ingerek értékelését vizsgáló kísérletben (valójában ez a hangulatindukció); és egy ezt követő szociális ítéletekről szóló vizsgálatban. A kísérleti személyek egyesével nézték meg a három film valamelyikét, melyek vagy a vidám, vagy a semleges, vagy a szomorú hangulatot voltak hivatva megteremteni. Amint ez a film véget ért, a kísérletvezető a kísérleti személyhez fordult a következő szavakkal: „Azt hiszem, nincsen nálam az ingereket vizsgáló válaszív. Amíg előkészítem a következő feladatot, átmenne a szomszéd szobába és megkérné az ott lévő hölgyet, hogy adjon magának egy válaszívet? Tudni fogja, mit akar." Ebbe minden személy beleegyezett, és elindult a válaszívért a szomszéd szobába, ahol egy álcázott magnót rejtettünk el, amivel felvettünk mindent, amit mondtak. Egyesek rögtön megfogalmazták kérésüket, amint beléptek a szobába; mások vártak egy kicsit ezzel, néhány megjegyzést téve először (például bemutatkoztak vagy meggyőződtek afelől, hogy jó helyen járnak-e). Azt is rögzítettük és később elemeztük, hogy a hangulatnak milyen hatása van a kérdés megfogalmazásának halogatására. Egy körülbelül 20 perces elterelő feladat után azt is mértük, hogy a kísérleti személyek mennyire tudják szó szerint felidézni az általuk mondottakat. A felidézés pontosságát egy tízpontos skálán független bírák ítélték meg, akik nem tudtak a hangulatindukálásról. Végül a kísérleti személyektől megkérdezték, valóban azt hitték-e, hogy a válaszív elkérése egy spontán kérés volt, nem pedig a kísérlet része. Úgy tűnt, hogy a „természetes” kérési helyzet megteremtésében és rögzítésében valóban sikeresek voltunk.

A hangulat hatása a kérés minöségére. A hangulat manipulálása sikeres volt, mivel azok, akik a vidám filmet látták, szignifikánsan jobb hangulatban voltak, mint a kontrollcsoport, s azok, akik a szomorú filmet látták, szignifikánsan rosszabb hangulatban voltak. A különböző hangulatban lévő (vidám, közömbös, szomorú) emberek kérdéseit két bíráló értékelte a következő kétpólusú skálák mentén: udvarias-udvariatlan, közvetlen-közvetett, barátságos-barátságtalan, kertelő-nem kertelő, egyszerű-összetett és kifinomult-nem kifinomult. A kérések értékelésének főkomponens-elemzésekor azt találtuk, hogy az első három skála (udvarias-udva- 
riatlan, közvetlen-közvetett, barátságos-barátságtalan) egy faktorba sorolható; ez az udvariasság faktora. Az egyszerü-összetett és kifinomult-nem kifinomult skála került a második faktorba, mely a kidolgozottság nevet kapta. A harmadik faktor, a kertelő, mindössze egy skálából állt (kertelő-nem kertelő).

Az eredmények megint csak azt mutatták, hogy a hangulat szignifikáns főhatással volt a kérések udvariasságára. A szomorú emberek udvariasabb, barátságosabb és kevésbé közvetlen kéréseket használtak, mint a kontrollcsoport; a vidám emberek pedig közvetlenebb és kevésbé udvarias kéréseket fogalmaztak meg (4. ábra). A hangulat a kérések összetettségét is befolyásolta: a szomorú kísérleti személyek összetettebb és kifinomultabb kéréseket fogalmaztak meg, mint a kontrollcsoport, akik viszont kifinomultabban kértek, mint a vidám emberek (4. ábra). Végül, a hangulat a kertelés faktorát is befolyásolta: a vidám emberek kevesebbet, a szomorú emberek többet kerteltek kérésük során, mint a kontrollcsoport. Ezek az eredmények megerősítik az első három kísérlet által leírtakat, és bebizonyítják, hogy a hangulat jelentős hatást gyakorol a megfogalmazott kérésekre, még természetes körülmények között is.

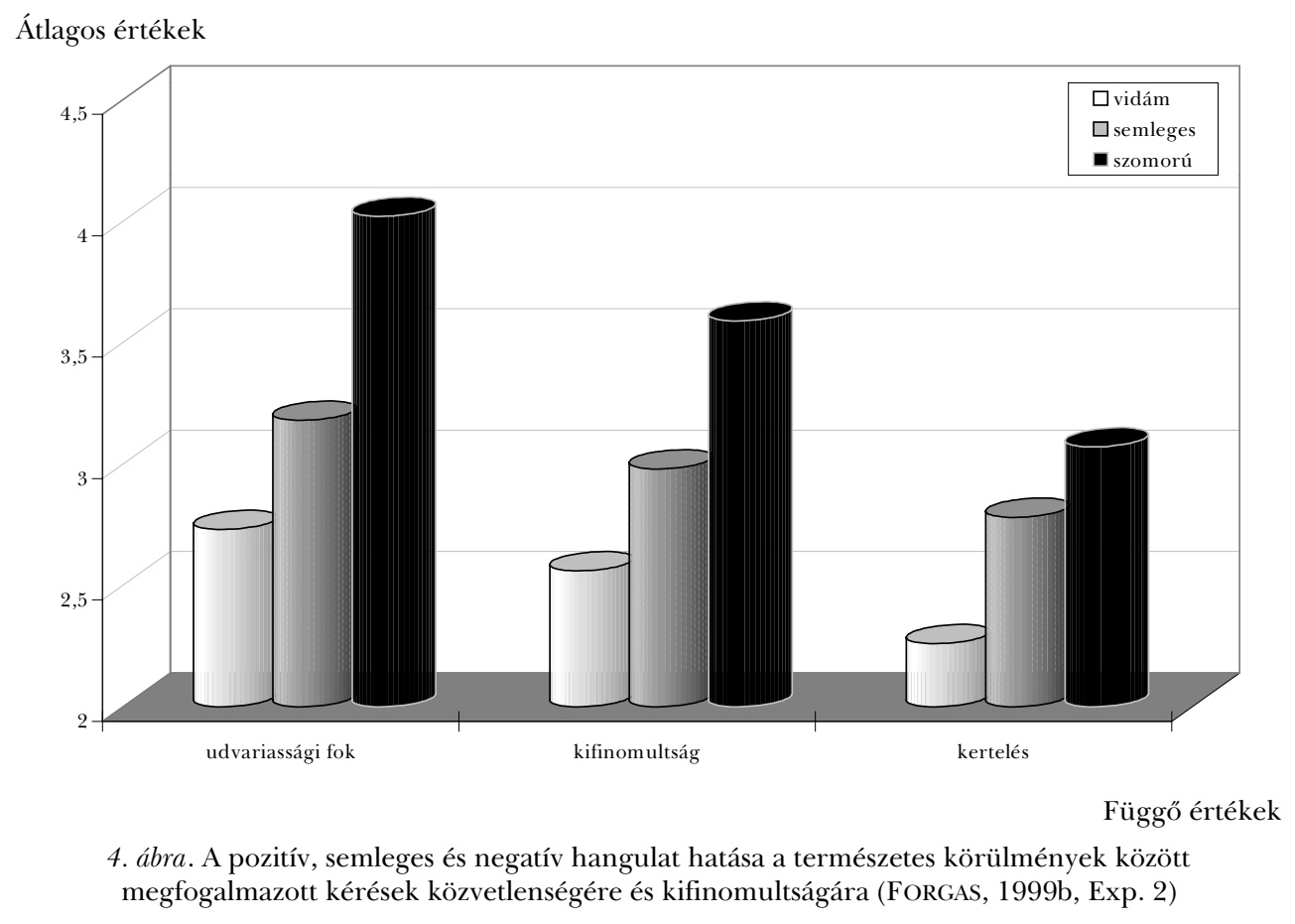

A hangulat hatása a kérések halogatására. Nem minden kísérleti személy fogalmazta meg azonnal a kérését, mihelyt belépett a szobába. A hangulat késlekedésre gyakorolt hatását szintén értékeltük úgy, hogy minden kéréshez egy számot rendeltünk, ami kifejezte, hogy maga a kérés hányadik volt a személy által közölt kije- 
lentések sorában. Így az a kérés, mely a szobába lépéskor azonnal elhangzott, 1-es értéket kapott; ha a negyedik (vagy annál is későbbi) kijelentés volt, akkor 4-es értéket rendeltünk hozzá. Az eredmények azt mutatták, hogy a szomorú kísérleti személyek szignifikánsan többet késlekedtek kérésük megfogalmazásával, mint a kontrollcsoport vagy a vidám kísérleti személyek $(\mathrm{M}=1,13$, illetve 1,54 , illetve 2,06), ami megfelel az óvatosabb, védekező szóbeli stratégiának, amiről korábban már szó volt.

A hangulat és a kérés udvariasságának szerepe a felidézésben. A hangulati hatás (vidám, semleges, szomorú) és a kérés udvariasságának (udvarias, közepesen udvarias, udvariatlan) szerepét a felidézésre kétszempontú varianciaanalízissel vizsgáltuk. A kéréseket három csoportba soroltuk - udvarias, közepesen udvarias és udvariatlan - az alapján, hogy az összes kérés első, középső vagy alsó harmadába tartoztak-e. A kéréseket két független bíráló értékelte mindhárom hangulati csoportnál. Az eredmények szignifikáns főhatást mutatnak a hangulatra nézve. A szomorú emberek szignifikánsan jobban emlékeztek kéréseikre, mint a vidám emberek (5. ábra). Ez az eredmény különösen érdekes, hiszen a szomorú kísérleti személyek általában bonyolultabb és kifinomultabb kéréseket fogalmaztak meg (4. ábra), ennek ellenére pontosabban emlékeztek ezekre a bonyolultabb kifejezésekre, mint a vidám alanyok. Ezen emlékezeti hatások arra engednek következtetni, hogy a szomorúság szisztematikusabb és analitikusabb feldolgozási stratégiát eredményez, aminek a későbbi felidézésre is jótékony hatása van (CLARK, IsEN, 1982; ForGAS, 1995a; 2000, in press).

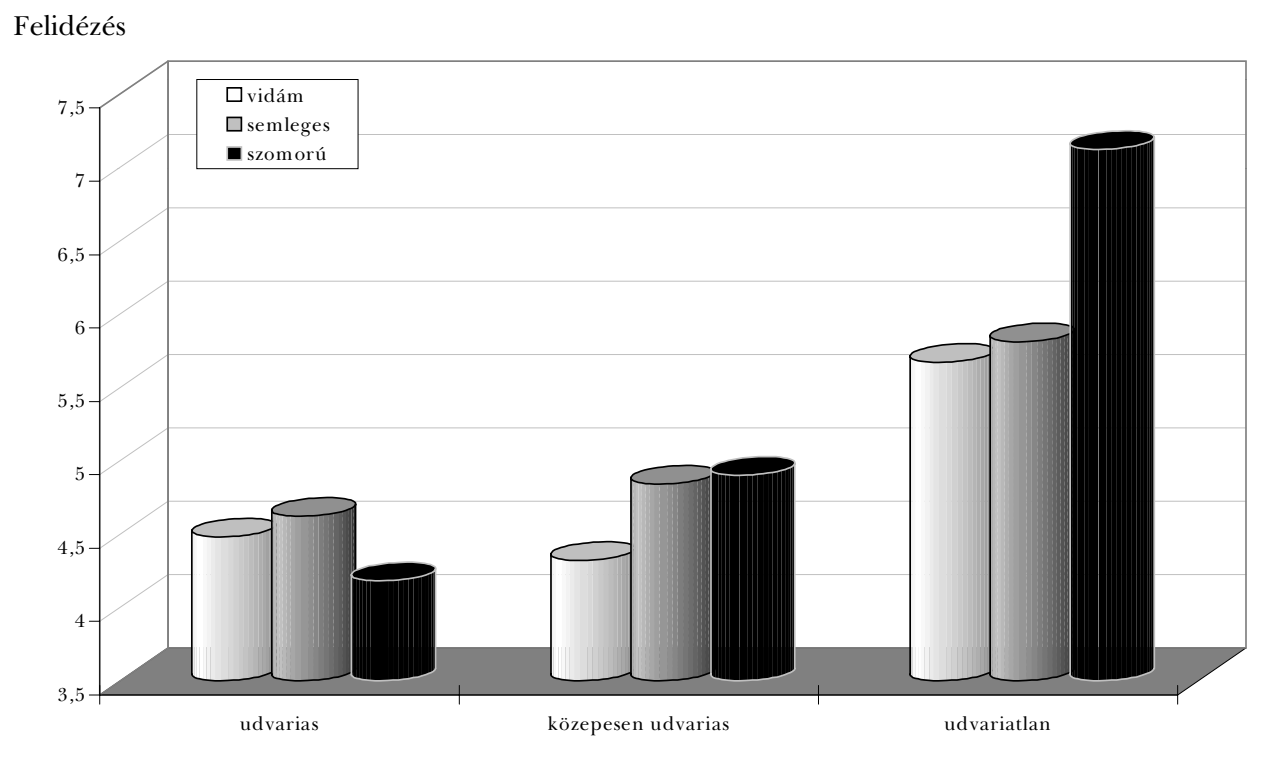

A kérés típusa 5. ábra. A hangulat hatása a felidézésre közvetlen, kevésbé közvetlen és közvetett kéréseknél (FORGAS, 1999b) 
A kérés udvariasságának is jelentős hatása volt a felidézésre. Az udvariatlan kéréseket szignifikánsan pontosabban idézték fel, mint akár a közepesen udvarias, akár az udvarias kéréseket (5. ábra), ami megfelel annak az állításnak, hogy az ilyen üzeneteket kifinomultabban és alaposabban dolgozzuk fel (GIBBS, 1983; KiTAYAMA, BURNSTEIN, 1988). Jelentős összefüggést találtunk a hangulat és a kérés udvariassági foka, valamint ezek felidézésre gyakorolt hatása között. Az udvarias és a közepesen udvarias kérésekre való emlékezést nem nagyon befolyásolta a hangulati állapot. Az udvariatlan és szokatlan kérdésekre azonban szignifikánsan jobban emlékeztek a szomorú kísérleti személyek, mint a kontrollcsoport vagy a vidám személyek (5. ábra). Ez az eredmény alátámasztja az AIM alapállítását, miszerint a hangulat hatása akkor a legnagyobb, amikor a kommunikátor mélyebb és egyénibb feldolgozást használ.

Az eredmények közvetlen kapcsolatot tártak fel a hangulati hatás erőssége és az egyes kérések feldolgozásának minősége között, mint ahogy ezt a felidézési feladat bebizonyította. Összefoglalva, ezek a kísérletek egy új területre - az interperszonális kommunikáció területére - terjesztették ki a korábbi tanulmányok vizsgálódásait, melyek bemutatták, hogy a hangulatnak milyen szerepe van a figyelemre, tanulásra, emlékezésre és az ítéletekre (BOWER, 1991; ClORE, SCHWARZ, CONWAY, 1994; FORGAS, 1995a). Jelen vizsgálatunkban a kísérleti személyeknek az volt a feladatuk, hogy kéréseket fogalmazzanak meg, és azokat tegyék fel egy ismeretlen személynek egy komplex és újszerű helyzetben. A kérés megfogalmazásánál részletes feldolgozási stratégiát kellett használniuk, hogy megbecsülhessék a különböző szóba jöhető kérési formák használatából adódó nyereséget és veszteséget. A megfogalmazás módja megfelelt előzetes várakozásainknak: a szomorú emberek pesszimistábban ítélik meg kérésük kimenetelét, ezért udvariasabb kérési formát használnak, míg a vidám emberek közvetlenebb módon fogalmaznak, mivel optimistábban ítélik meg kérésük lehetséges eredményességét. Ezt az értelmezést a késlekedés ténye is alátámasztja: a szomorú kísérleti személyek jóval tovább halogatták kérésüket, mint a vidámak. Ezek az eredmények alátámasztják az AIM modellt; a hangulat hatása akkor a legerősebb, amikor egy nehéz kognitív feladat teljesítéséhez alapos, részletes feldolgozás szükséges. Vajon a hangulat azt is befolyásolja-e, ahogy az emberek a feléjük intézett kéréseket feldolgozzák? Ezt a kérdést is meg kell vizsgálnunk.

Ötödik vizsgálat:

A hangulat hatása a természetes kérésekre való reagálás esetében

Eddig arra összpontosítottunk, hogy milyen hatással van a hangulat arra, ahogyan a kéréseket megfogalmazzuk. A hangulat azonban befolyásolhatja azt is, hogy az emberek miként reagálnak ezekre az üzenetekre. Bár van néhány bizonyíték arra nézve, hogy a hangulat hat az engedelmesség mértékére (MILBERG, CLARK, 1988), valamint a cselekvésre felszólító üzenetekre való reagálás mikéntjére (PETTY, GLEICHER, BAKER, 1991), keveset foglalkoztak azzal, hogy milyen szerepe van a hangulatnak egy hozzánk intézett kérés feldolgozásánál. Egy vidám és egy szomo- 
rú ember igen eltérő módon értelmezhet egy hozzá intézett kérést hangulata információs hatása miatt, ami az érzelem-bevésődés mechanizmusok révén fejti ki hatását. Ennek következtében a vidám emberek valószínűleg pozitívabban értelmezik a hozzájuk intézett kérést, és így összességében jobban is engedelmeskednek. Ezzel szemben a rossz hangulat negatívabb értékelést és asszociációkat eredményez (Berkowitz, 1993; Forgas, Bower, KrantZ, 1984; SEdikides, 1992, 1995), így a kérésre fenntartásokkal reagálunk, ami csökkenti annak teljesítésére való hajlandóságunkat (FORGAS, 1994; WhEELER, MiYAKe, 1992). Ezek a hangulati hatások erősebbek a szokatlan és udvariatlan kérések esetén, mivel ezek megértése mélyebb és egyénibb feldolgozási stratégiát igényel. Mostani terepkísérletünk a címzettek hangulatán és a kérés udvariasságán túl a kért szívesség nagyságát is manipulálta (FORGAS, 1998b, Exp. 1).

Egy könyvtárban 96 ott tanuló diáknál indukáltunk pozitív vagy negatív hangulatot egy jól álcázott eljárással. Üres asztalokon a kísérletvezetők nagy borítékokat hagytak, melyek pozitív vagy negatív jellegű képeket tartalmaztak (vicces karikatúrákat vagy balesetekről készült képeket). Az asztalokhoz leülő diákoknak elegendő idôt hagytuk ahhoz, hogy kinyissák a borítékokat és megnézzék a képeket. Ezután egy beépített ember odament hozzájuk, és néhány írólapot kért. A kérések udvariassági foka (udvarias, átlagos, udvariatlan) és a kért szívesség nagysága (egy vagy tíz lapot kért) változó volt. Néhány perccel a kérés elhangzása után egy másik beépített ember ment az asztalhoz, és elmagyarázta, hogy az előző kérés egy szociálpszichológiai kísérlet része volt; majd megkérte a kísérleti személyt, hogy töltsön ki egy rövid kérdőívet, ami a kérés megítélését és az arra adott reakciót vizsgálta. A kísérletet 2-2-2 független csoporttal végeztük, ahol a független változók a hangulati állapot (vidám, szomorú), a kérés udvariassági foka (udvarias, udvariatlan) és a kért szívesség nagysága (kicsi, nagy) voltak.

A hangulat hatása a kérés megitélésére. Összességében a kísérleti személyek szignifikánsan negatívabbnak ítélték hangulatukat a negatív dolgokat ábrázoló képek esetén, mint azok, akik vidám képeket néztek, ami bizonyítja a hangulatindukció eredményességét. Az értékelő kérdőíven minden kísérleti személynek négy skála mentén kellett megítélnie a hozzá intézett kéréseket: udvarias-udvariatlan; megszokott-szokatlan; megterhelö-nem megterhelö; agresszív-nem agresszív. A fökomponens-elemzés kimutatta, hogy a négy skála értékei nagymértékben korrelálnak, és így azok egy faktorba csoportosíthatók. Ezek alapján a négy skálát egy kategóriába sorolhattuk, ez lett a kérés megitélése. Az érzelem-befolyás hipotézist igazolva a negatív hangulatban lévő személyek szignifikánsan kritikusabban és negatívabban ítélték meg a hozzájuk intézett kéréseket, mint a pozitív hangulatú emberek (6. ábra). A fó hipotézisünk, miszerint a hangulati hatás viszonylag nagyobb az udvariatlan és szokatlan kérések esetén - mivel ezek egyénibb feldolgozást igényelnek -, szintén igazolódott, amit a hangulat és a kérés udvariassági foka közt fennálló szignifikáns kétirányú összefüggés jelzett. Az udvarias és szokásos kérések megítélésére (Kitayama, Burnstein, 1988; Langer, Blank, Chanowitz, 1978) csak kismértékben volt hatással a hangulati állapot (6. ábra). Ezzel szemben a szokatlan és udvariatlan kérések megítélése, melyek nem felelnek meg szokásos 
elvárásainknak - és így mélyebb és egyénibb feldolgozást igényelnek -, szignifikáns hangulati hatást mutatott (6. ábra).

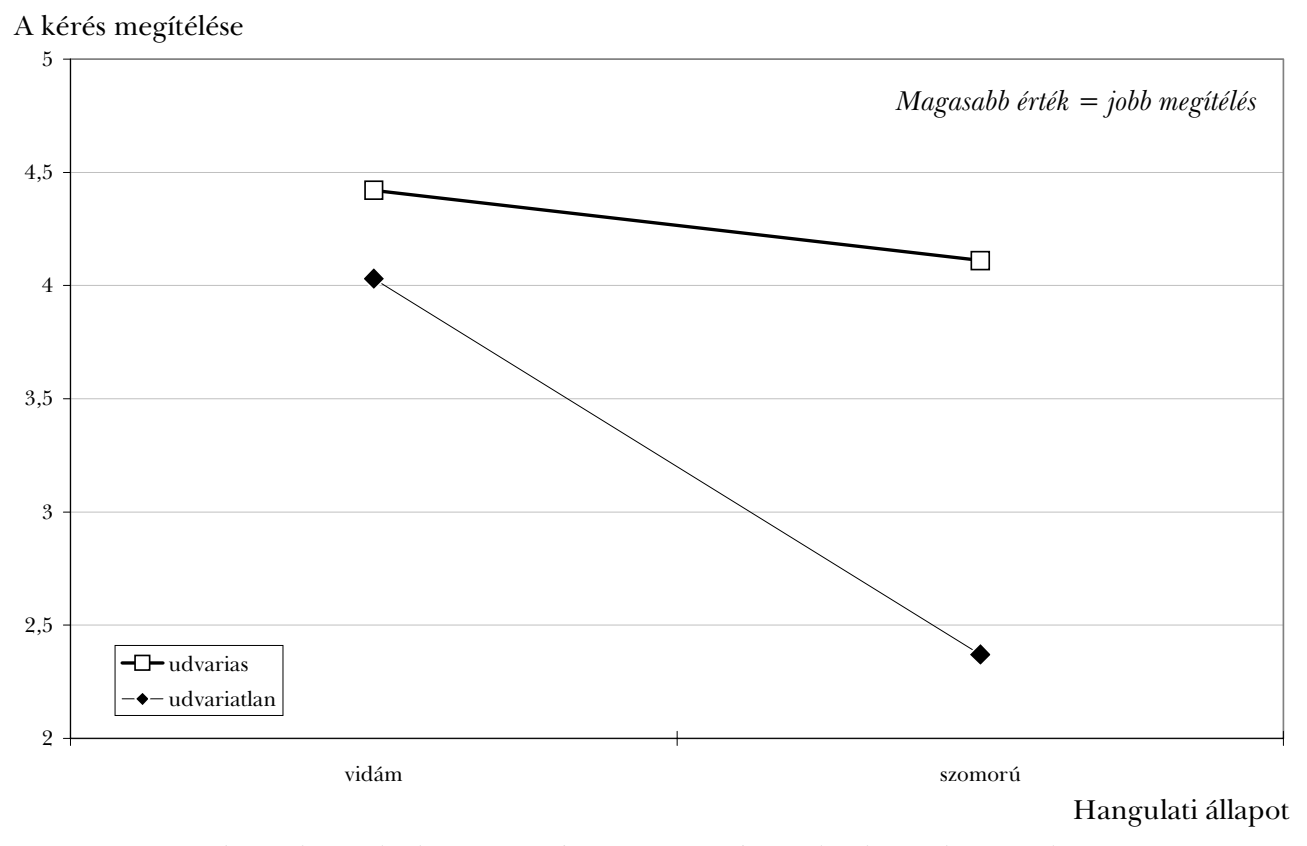

6. ábra. A hangulat hatása az udvarias és az udvariatlan kérések megítélésére.

Udvariatlan kérések esetén a hangulat hatása nagyobb (FORGAS, 1998b)

A hangulat hatása a kérések teljesitésére. A kérés teljesítésének mértékét kétféleképpen mértük: (a) a kísérleti személyek önbeszámolója alapján, és (b) a kérés tényleges, megfigyelhető teljesítése alapján. Háromszempontú varianciaanalízis segítségével elemeztük a hangulat, az udvariasság és a kért szívesség nagyságának hatását a kérés teljesítésére (mind az önbeszámoló, mind a megfigyelt viselkedés szintjén), valamint a megfigyelt engedelmességi szintet még egy khi-négyzet próbával is megvizsgáltuk. A hangulatnak szignifikáns fóhatása volt az önbeszámolón alapuló engedelmesség szintjére: a jó hangulatban lévők inkább engedelmeskedtek, mint a rossz hangulatban lévők. A tényleges viselkedésből nyert adat is megerősítette ezt: akik jó hangulatban voltak, azok inkább teljesítették a kérést, mint azok, akiknek rossz volt a hangulata. Ezek az eredmények azt mutatják, hogy a hangulatnak nemcsak arra van jelentős hatása, ahogyan az emberek a stratégiai szóbeli üzeneteket értékelik, hanem arra is, ahogyan ezekre reagálnak. Különösen érdekes a hangulat és a kérés udvariassága között megfigyelhető szignifikáns összefüggés mind az önbeszámolón alapuló, mind a megfigyelt viselkedésen alapuló engedelmességi szint esetében. Függetlenül a kért szívesség nagyságától, a hangulatnak mind a szokásos, mind az udvarias kérdések esetén csekély hatása volt az engedelmességre (7. ábra). A szokatlan és udvariatlan kéréseknél azonban, mivel ezek 
mélyebb és egyénibb feldolgozási stratégiát igényelnek, a jó hangulatban lévő emberek szignifikánsan nagyobb engedelmességi szintről számoltak be, mint a rossz hangulatban lévők, függetlenül a kérés nagyságától (7. ábra). Ezek az eredmények bizonyítják az Érzelem-befolyás modell (AIM) helyességét, és megerősítik azt a tényt, hogy a hangulatnak szignifikáns, de erősen kontextusfüggő hatása van arra, ahogyan az emberek a kérésekre reagálnak.

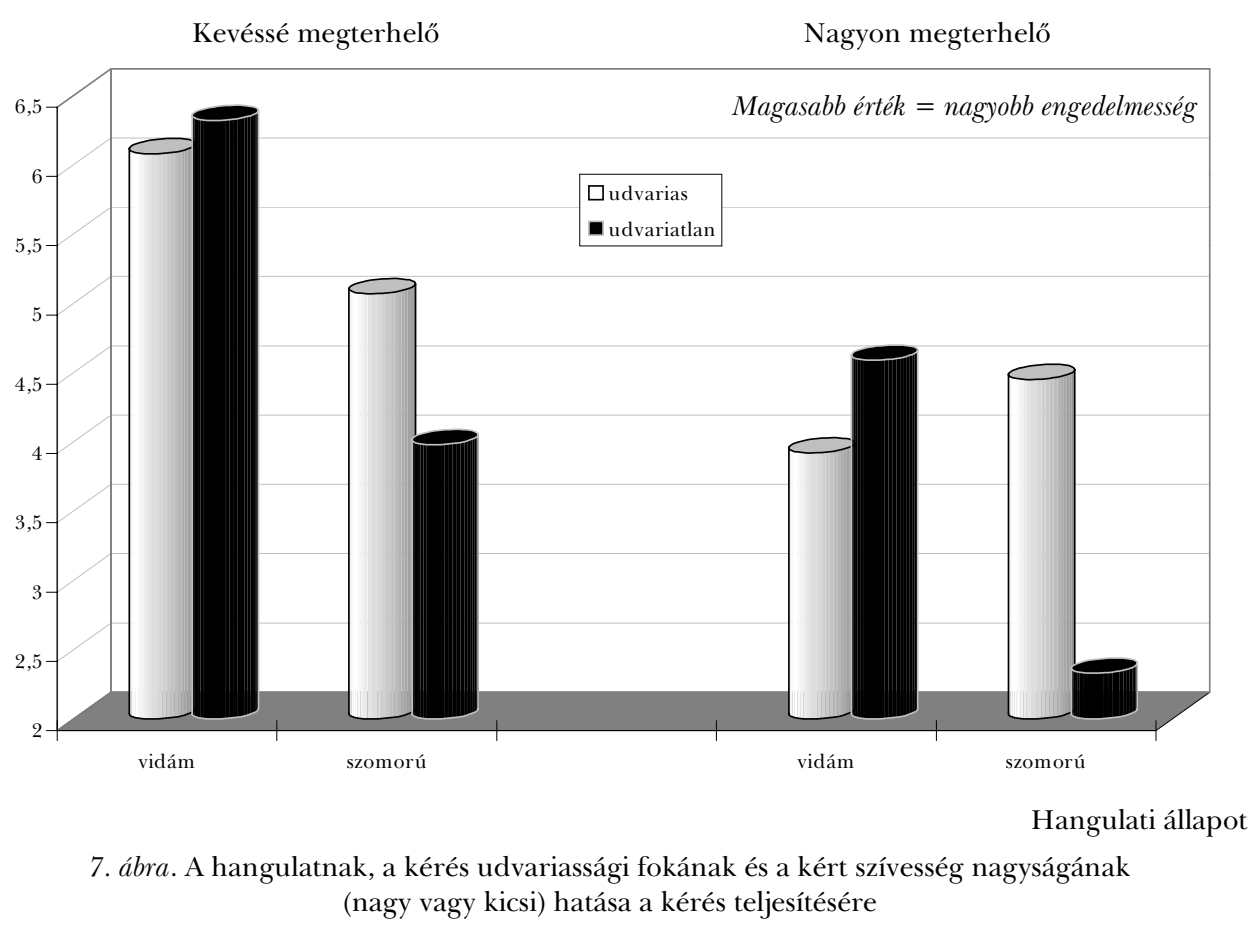

\section{Hatodik vizsgálat: \\ A hangulat hatása a hozzánk intézett kérések felidézésére}

Az előző vizsgálat kimutatta, hogy a hangulat hatása akkor a legerősebb, amikor a kérés igen közvetlen és udvarias, és így egyénibb feldolgozást igényel. Ezek az eredmények kiterjesztették az érzelem-befolyáselméletet egy új területre, a stratégiai szóbeli kommunikációra való reagálás területére. Ha a kísérleti személyek udvarias kérések esetén valóban másfajta feldolgozási stratégiát használnak, mint udvariatlan kérések esetén, ennek a ténynek tükröződnie kell azon képességükben, hogy mennyire pontosan tudnak visszaemlékezni a hozzájuk intézett üzenetekre. Az alábbiakban ezt a jelenséget vizsgáljuk meg. Jelen vizsgálatunkban számos módszertani újítást is alkalmaztunk: bevezettünk egy harmadik hangulati állapo- 
tot, mely kontrollként funkcionált, valamint a kettő helyett három udvariassági szintet különböztettünk meg (udvarias, közepesen udvarias és udvariatlan). A korábbiaktól eltérően a különböző hangulati állapotok megteremtéséhez képek helyett írott szövegeket használtunk. Végül, ebben a vizsgálatban nemcsak azt tanulmányoztuk, hogy a hangulat milyen hatással van a kérés észlelésére, hanem azt is, hogy a hangulati állapot függvényében milyennek találták magát a kommunikátort.

A kísérleti eljárás lényegét tekintve hasonló volt a korábbi kísérletekéhez. A kísérleti személyek $(\mathrm{N}=144)$ könyvtárban tanuló diákok voltak, akik egy üres könyvtári asztalon lévő borítékban egy egyoldalas szöveget találtak, ami a pozitív, semleges vagy negatív hangulatot volt hivatott megteremteni. Amikor egy tanuló leült egy asztalhoz, elegendő időt hagytunk neki ahhoz, hogy kinyithassa a borítékot és elolvashassa a szöveget. Ez után egy beépített ember odament a kísérleti személyhez, és néhány írólapot kért. A kérések udvariassági foka (udvarias, átlagos, udvariatlan) és a kért szívesség nagysága (egy vagy tíz lapot kért) változó volt. Néhány perccel a kérés elhangzása után a kísérleti személyeket megkérték, hogy töltsenek ki egy rövid kérdőívet az előbbi eseményről. A kérdőívben arra kérték a kísérleti személyeket, hogy: a) írják le - ha lehet, szó szerint - a néhány perccel ezelőtt feléjük intézett kérést; $b$ ) értékeljék a kérést négy skála mentén (megterhelő-nem megterhelö; udvarias-udvariatlan; megszokott-szokatlan; agresszívnem agresszív); c) értékeljék a kommunikátorról kialakult benyomásukat öt hétfokozatú bipoláris skálán (rokonszenves-ellenszenves; barátságos-barátságtalan; félénk-merész; udvarias-udvariatlan; magabiztos-félszeg); d) értékeljék a kérés teljesítésére való hajlandóságukat egy hétfokú skálán (a lehető legjobban - a lehető legkevésbé hajlandó); e) értékeljék hangulati állapotukat (visszajelzésképpen) a következő hétfokú skálákon: pozitív-negatív, jó-rossz, vidám-szomorú. A kérésekre való emlékezés helyességét két független bíráló értékelte úgy, hogy minden felidézett kérdést 0-tól 3-ig pontoztak aszerint, hogy a kísérleti személyek mennyire emlékeztek pontosan az elhangzott szavakra. A bírálók által adott pontszámok belső reliabilitása 0,89 lett. A kísérlet 3-3-2 elrendezésű volt, ahol a független változó a hangulat (vidám, semleges, szomorú), a kérés udvariassága és a kért szívesség nagysága volt.

A hangulat hatása a kérés megitélésére. Az eredmények azt mutatták, hogy a hangulatindukció eredményes volt: azok, akik a szomorú történeteket olvasták, szignifikánsan rosszabbnak értékelték a hangulatukat, mint a kontrollcsoport alanyai, míg azok, akik a vidám szövegeket olvasták, szignifikánsan jobbnak értékelték a hangulatukat. A négy skálán (udvarias-udvariatlan; megszokott-szokatlan; megterhelő-nem megterhelő; agresszív-nem agresszív) megítélt kéréseket faktoranalízisnek vetettük alá, és egy faktorba - a kérés megítélése faktor - csoportosítottuk. Háromszempontos varianciaanalízissel értékeltük a hangulat, az udvariasság mértékének és a kért szívesség nagyságának a hatását a kérés megítélésére. A kért szívesség nagysága és a kérés udvariassági foka szignifikáns föhatást mutatott a kérés megítélésére nézve: a nagy szívességet kérő, udvariatlan kéréseket szignifikánsan negatívabbnak ítélték, mint a kis szívességet kérő, udvarias kéréseket. 
A kérés megítélése

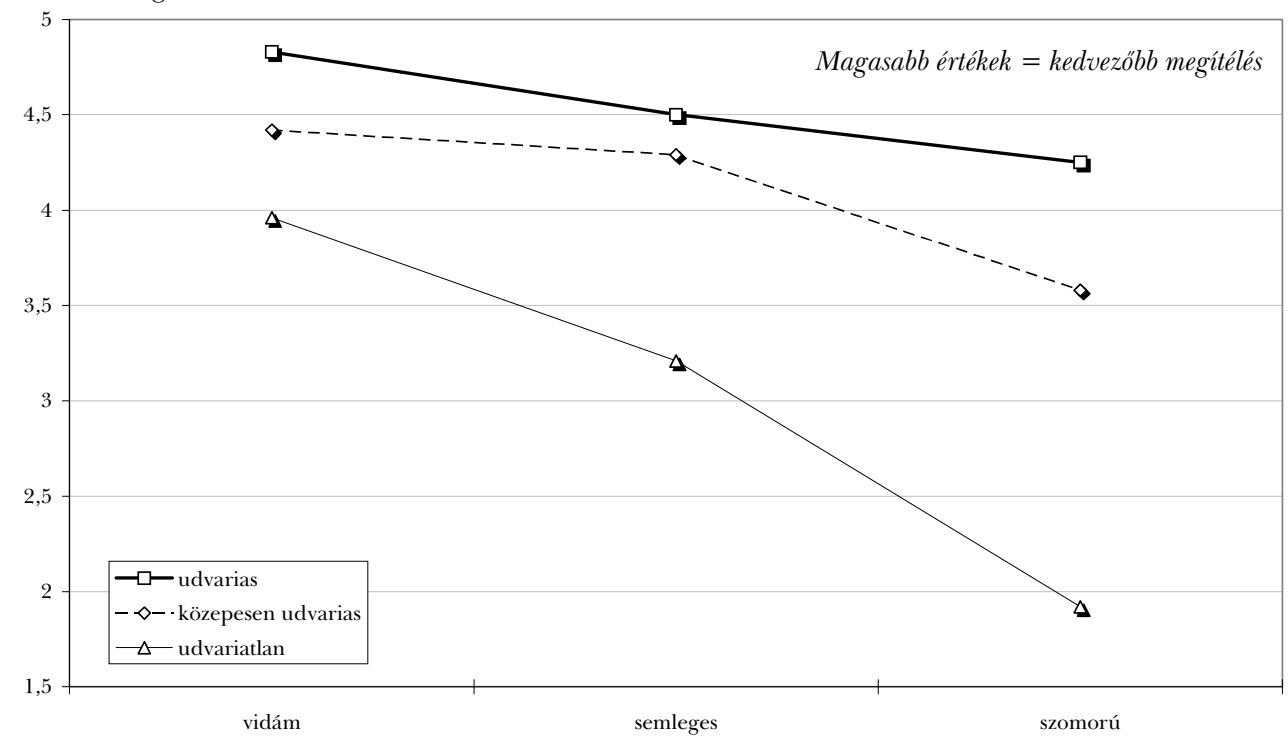

Hangulati állapot

Felidézés

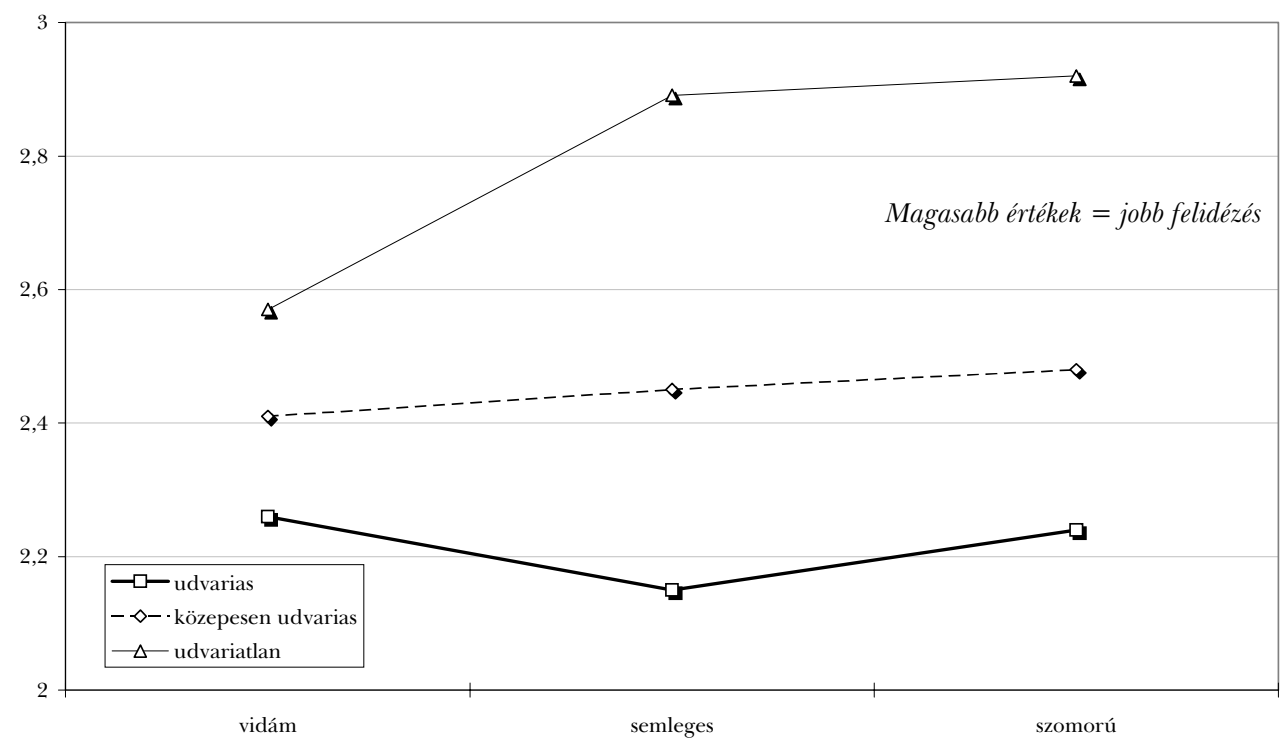

Hangulati állapot

8. ábra. A hangulat és a kérés udvariassági fokának összefüggése a kérések (a) megítélésében (felső ábra) és azok (b) felidézésében (alsó ábra)

A hangulati hatás erősebb az udvariatlan, mint az udvarias kérések esetén 
A kérés megítélése szempontjából most természetesen a hangulat hatása érdekel minket a legjobban. A hangulatnak is szignifikáns föhatása volt: a rossz hangulat negatívabb megítélést eredményezett, a jó hangulatnak pedig pozitív hatása volt (8. ábra). Ezek az eredmények megerősítik azt a tényt, hogy a hangulat (különösen az érzelem befolyásoló hatása) jelentős szerepet játszik a valós szituációban elhangzó szóbeli kérések értelmezésében. Szignifikáns összefüggést is kimutattunk a hangulat és a kérés udvariassági foka, valamint a kérés megítélése között. A befogadó hangulata kevésbé befolyásolta az udvarias és szokványos kérések megítélését, mint a szokatlan és közvetlen kérésekét, melyek megsértették a normatív elvárásokat, ezzel mélyebb és egyénibb feldolgozást téve szükségessé.

A hangulat hatása a hallott kérésekre való emlékezésre. A kérésekre való emlékezést három szempontból vizsgáltuk: $a$ ) a hangulat, $b$ ) a kérés udvariassági fokának és c) a kért szívesség nagyságának szempontjából. Az udvariatlan kérésekre szignifikánsan jobban emlékeztek, mint a közepesen udvarias kérésekre, amelyekre azonban jobban emlékeztek, mint az udvarias kérésekre. Ez az eredmény alátámasztja azt az elméletet, miszerint a szokatlan kéréseket valószínủleg mélyebben és szisztematikusabban dolgozzuk fel, ami jelentősen segíti a kérés későbbi felidézését (GIBBS, 1985; KITAYAMA, BuRNSTEIN, 1988). A kért szívesség nagyságának nem volt szignifikáns hatása a felidézésre, ami ismét csak azt a tényt erősíti, hogy a kérés udvariassági foka fontosabb a feldolgozási stratégiák és a felidézés szempontjából, mint a kért szívesség nagysága (BOHNER és mts., 1992; GiBBS, 1985). Szignifikáns összefüggést találtunk a hangulat és a kérés udvariassági foka, valamint a felidézés között. A hangulatnak nagyobb hatása volt a szokatlan és udvariatlan kérésekre való emlékezés esetében, mint az udvarias és megszokott kérések felidézésére (8. ábra). Ez az emlékezeti hatás megegyezik azzal a már bemutatott jelenséggel, hogy arra az információra, amelyik mélyebb és egyénibb feldolgozást igényel - mint például a szokatlan kérések -, valószínúleg jobban hat az aktuális hangulati állapotunk.

Egy másik érdekes eredmény szignifikáns összefüggést mutatott ki a hangulat és a kért szívesség mérete, valamint a kérésre való emlékezés között. A kis szívességekre jobban emlékeztek pozitív, mint negatív hangulatban, míg a nagyobb szívességek felidézése pontosabb volt negatív, mint pozitív hangulatban. Ugy tűnik, hogy a vidám emberek azért emlékeznek jobban a kis szívességekre, mert ezek teljesítése nem megerőltető, és ez valószínủleg összhangban van aktuális lelkiállapotukkal. Ezzel szemben a szomorú emberek a nagyobb kéréseket jobban fel tudják idézni, mivel kongruencia van az aktuális hangulatuk és a nehéz kéréssel járó rossz érzés között.

A hangulat hatása a kérés teljesitésére. Elvárásainknak megfelelően a hangulat szignifikáns hatást gyakorolt mind az önbeszámolón alapuló, mind a megfigyelt teljesítési szintre. A vidám emberek hajlamosabbnak mutatkoztak a kérés teljesítésére, mint a kontrollcsoport, míg a szomorú kísérleti személyek szignifikánsan kevesebb hajlandóságot mutattak erre (9. ábra). A ténylegesen megfigyelt viselkedés is azt mutatta, hogy a jó hangulatban lévő személyek szignifikánsan többször teljesítették 
Engedelmességi szint

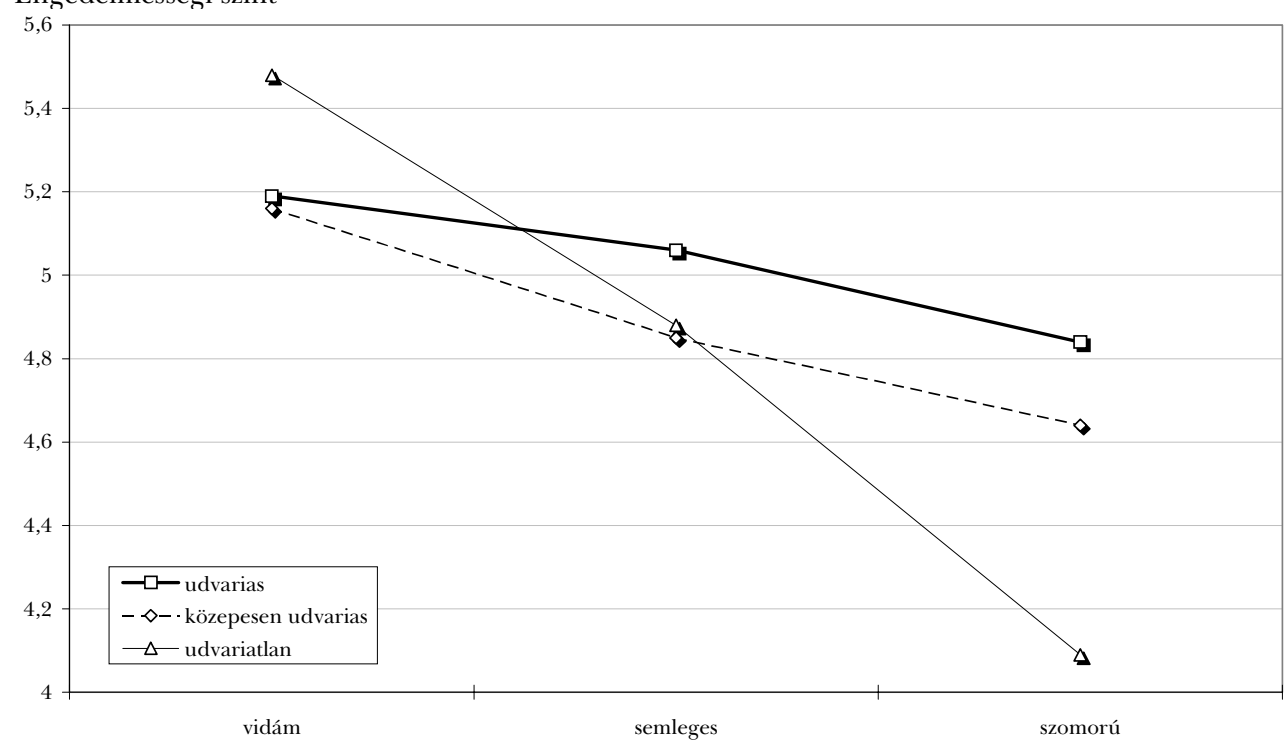

Hangulati állapot

Megítélés

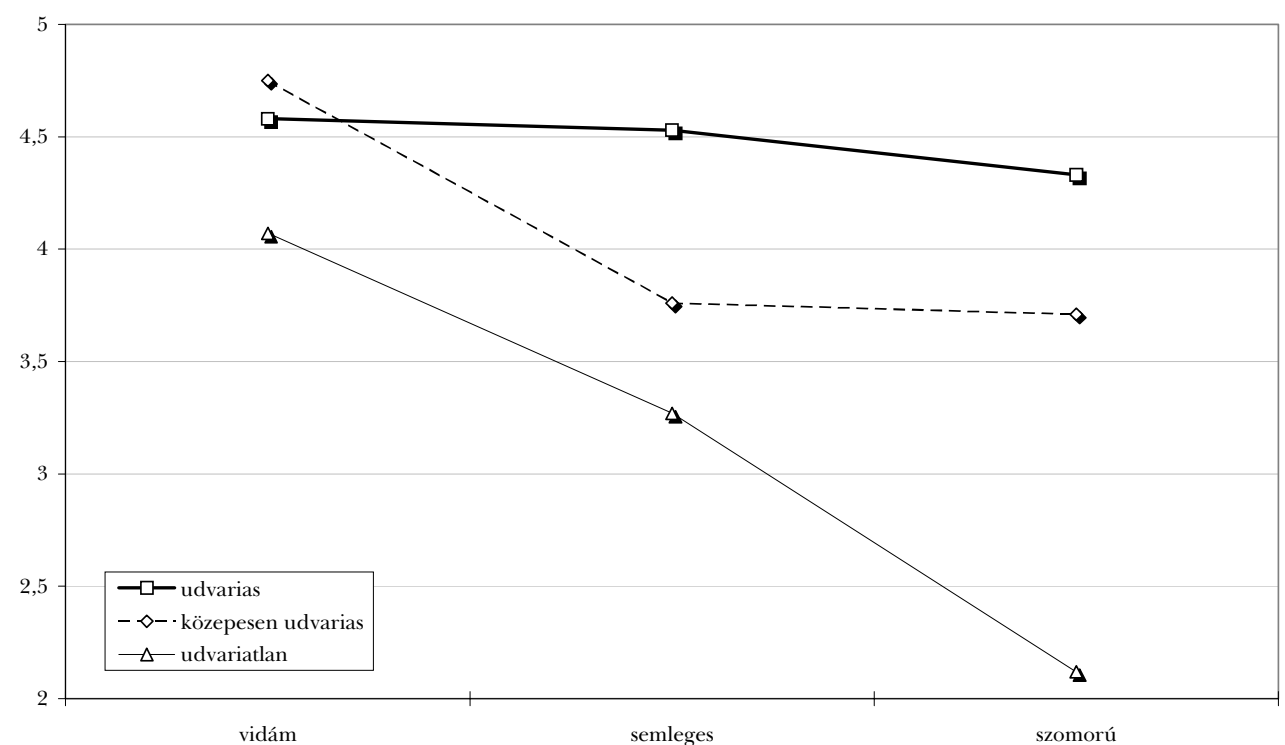

Hangulati állapot

9. ábra. A hangulat és a kérés udvariassági fokának összefüggése a (a) kérés teljesítésével (felső ábra) és (b) a kérdező megítélésével (alsó ábra)

A hangulat hatása erősebb az udvariatlan és szokatlan kérések esetében, mint az udvariasoknál 
a kéréseket, mint a rossz hangulatúak. Ezek az eredmények arra engednek következtetni, hogy a hangulatindukált asszociációk fontos szerepet játszanak abban, ahogyan az emberek a hozzájuk intézett stratégiai üzenetekre reagálnak. Úgy tűnik, hogy a kísérleti személyek akkor engedelmeskedtek jobban, „amikor jó hangulatban voltak... és ... akkor engedelmeskedtek kevésbé, amikor rossz hangulatban voltak, mivel a hangulati állapot olyan gondolatokat hív elő a kommunikátorról és magáról az üzenetről, melyek kongruensek az adott lelkiállapottal" (MilberG, Clark, 1988, 79). Ezek az eredmények megfelelnek elvárásainknak, miszerint az értelmezésre és a kérés teljesítésére akkor a legerősebb a hangulat hatása, amikor a személy mélyebb és egyénibb feldolgozást használ azért, hogy egy bonyolultabb feladattal (mint például szokatlan üzenetek megértése) megbirkózzon.

A kommunikátor észlelése. A kérés értékelésén túl a kísérleti személyek öt bipoláris skálán (rokonszenves-ellenszenves; barátságos-barátságtalan; félénk-merész; udvarias-udvariatlan; magabiztos-félszeg) értékelték a kéréssel hozzájuk forduló beépített személyt is. Főkomponens-analízissel két faktort definiáltunk: az értékelés faktora, melybe a kérő rokonszenvességének, barátságosságának és udvariasságának megítélése tartozott, és a magabiztosság faktora, melybe a kérő merészségét és magabiztosságát értékelő skálák tartoztak. A vidám emberek összességében pozitívabban ítélték meg a kéréssel hozzájuk forduló személyt, mint a semleges hangulatú vagy szomorú emberek; ezen túl ez a megítélés kedvezőbb volt udvarias, mint udvariatlan kérések esetén. Az Érzelem-befolyás elméletnek (AIM) megfelelően szignifikáns összefüggést találtunk a hangulat és a kérés megszokottsága, valamint a kérdező megítélése (értékelés) között. A hangulat hatása a benyomás kialakításában viszonylag nagyobb volt közvetlen és szokatlan kérések esetén, mivel ezek mélyebb feldolgozást igényelnek. A magabiztosság megítélését jelentősen befolyásolta a kérés udvariassági foka, valamint a kért szívesség nagysága. Nem meglepő módon a kérő személyét akkor ítélték magabiztosabbnak, amikor a kérés szokatlan és udvariatlan volt, és amikor tíz papírt kértek egy helyett (9. ábra). Az eredmények azt mutatják, hogy még rövid és felületes találkozás esetén is, ahol egyetlen kérés hangzott el, a kísérleti személyek képesek voltak megbízható és koherens benyomást alkotni a kérő személyéről. E benyomás milyenségét jelentősen befolyásolta a hangulat, valamint a kérés kísérletileg manipulált tulajdonságai. Ezek az eredmények megerősítik azt a tényt, hogy az aktuális hangulati állapot jelentős szerepet játszik abban, ahogyan a stratégiai üzeneteket értelmezzük, és ahogyan reagálunk rájuk; valamint abban, ahogyan a kommunikációs partnerünket észleljük és értékeljük.

Figyelembe véve a különböző adatokat (az emlékezeti teljesítményt, az engedelmesség mértékét, valamint a kérő személy megítélését), jelen vizsgálatunk alátámasztja azt a tényt, hogy az aktuális hangulat fontos szerepet játszik abban, ahogyan az emberek a feléjük intézett, többé-kevésbé mindennapos szóbeli üzeneteket értelmezik, és ahogyan azokra reagálnak. Ezek az eredmények megerősítik az érzelem hatására vonatkozó korábbi bizonyítékokat, melyek kimutatták, hogy a nehezebb és komplikáltabb kognitív feladatok megnövelik az érzelmi behatások 
valószínűségét a gondolkozásra és a viselkedésre (FIEDLER, 1991; FORGAS, 1992b, 1994, 1995b; SEDIKIDES, 1995). Ez az első eset, hogy az érzelem jelentős befolyásoló hatását valós stratégiai interakció keretében mutatták ki. A felidézési teljesítményből származó adatok szerint a legnagyobb valószínűséggel a szokatlan és udvariatlan kéréseket dolgozzuk fel a legkonstruktívabb generatív és részletesebb stratégiával (GIBBS, 1983), ezért emlékezünk ezekre jobban. Pontosan az ilyen kérések feldolgozása a legérzékenyebb az érzelem befolyásoló hatására.

\section{ÁLTALÁNOS MEGBESZÉLÉS ÉS KÖVETKEZTETÉSEK}

E vizsgálatok sikeresen bizonyították, hogy az aktuális hangulati állapot jelentős hatást gyakorol a szóbeli kommunikációs stratégiákra. Az első vizsgálat arra a következtetésre jutott, hogy a szomorú kísérleti személyek jobban kedvelik az udvarias kéréseket, mint a vidám emberek. A második vizsgálat azt mutatta ki, hogy nagyobb a hangulat hatása a mélyebb feldolgozást igénylő bonyolult és összetett helyzetekben. A harmadik vizsgálat megismételte ezeket az eredményeket, és kimutatta, hogy udvariatlan és szokatlan kérések esetén erősebb a hangulati hatás, mint megszokott és udvarias kérések esetén. A negyedik vizsgálat eredményei szerint az erősebb hangulati hatás kapcsolatban áll a mélyebb feldolgozási stratégiákkal, amit a felidézési teljesítményből származó adatok bizonyítottak. Az utolsó két kísérlet pedig meggyőző bizonyítékot talált arra, hogy a hangulatnak jelentős hatása van abban, ahogy az emberek feldolgozzák, értékelik a hozzájuk intézett kéréseket és reagálnak azokra.

Figyelemre méltó az a tény, hogy annak ellenére, hogy igen nagy az érdeklődés a hangulat gondolkodásra és ítéletalkotásra gyakorolt hatása iránt (BOwER, 1991; ClORE, SCHWARZ, CONWAY, 1994; ForGAS, 1995a, 2000, in press; MARTIN, Ward, ACheE, Wyer, 1993; Mayer, 1986; Salovey, Mayer, 1990; Sinclair, MARK, 1992), a hangulat valós társas viselkedésre gyakorolt hatását (mint például a nyelvhasználat) korábban nem kutatták. Eredményeink megfelelnek a legújabb, többszempontos feldolgozási elméletekben foglaltaknak (mint például az Érzelembefolyás modell, AIM), melyek az érzelem és a kogníció kapcsolatát vizsgálják. Ezek az elméletek azt állítják, hogy az érzelem akkor lehet a legnagyobb hatással gondolatainkra és viselkedésünkre, amikor olyan összetett helyzetben vagyunk, mely nyitott, részletes konstruktív és generatív feldolgozási stratégiákat igényel; ilyen, például egy kérés előtt adódó helyzet kiértékelése, ahol a helyzetből származó információ nem egyértelmű (FORGAS, 1995a). Az összes kísérletben azok a személyek, akik negatív hangulatban voltak, nagyobb valószínűséggel fogalmaztak meg udvarias és közvetett kéréseket, mint a vidám emberek, és ez a hatás erősödött akkor, amikor a helyzet vagy a kérés szokatlansága mélyebb feldolgozást igényelt. Az utolsó két kísérlet bebizonyította, hogy a hangulatnak jelentős hatása van arra, ahogyan a hozzánk intézett kérésekre reagálunk: a negatív hangulatban levő emberek inkább hoztak negatív ítéleteket, különösen akkor, amikor a kérések szokatlanok és udvariatlanok voltak. Ezek a hangulati hatások megint csak akkor voltak a legerősebbek, amikor az elhangzott kérések mélyebb és részletesebb fel- 
dolgozást igényeltek, ezért ezekre később jobban is emlékeztek. Ezeknek a kísérleteknek jelentôs elméleti és gyakorlati haszna van abban, hogy jobban megértsük, milyen szerepet játszik a hangulat hatása a szociális kogníció és a verbális kommunikációs stratégiák esetében.

Elméleti megfontolások. A verbális kommunikáció általában, és különösen a szívességek kérése, olyan különböző nehézségủ kognitív feladatok elé állítja a beszélőt, melyeket még mindig nem teljesen értünk. Ami bizonyos, az az, hogy a szóbeli üzenetek megfogalmazása és a rájuk való reagálás kifinomult következtetési stratégiákat igényel, mivel a beszélőnek figyelnie és értékelnie kell a beszélgetés helyzeti követelményeit, valamint a különböző eltervezett lépéseinek a várható kimenetelét (FORGAS, 1983, 1985). Mostanában különös figyelmet fordítottak a mindennapi nyelvhasználat pragmatikájára (BAVELAS, 1985; HERRMANN, 1983; VAN DIJK, 1985). Azonban azt, hogy a pszichológiai állapot (mint például az aktuális hangulat) milyen hatást gyakorol az emberek kommunikációs stratégiáira, alig vizsgálták. Újabb eredmények mégis azt mutatják, hogy még a csekély és múlékony hangulati állapot is jelentős változást idézhet elő abban, ahogy az emberek a társas környezet információit kezelik (FIEDLER, 1991; FORGAS, 1995b, 2000, in press; Martin, Ward, Achee, Wyer, 1993; Petty, Gleicher, Baker, 1991; SCHWARZ, BLESS, 1991; SiNCLAIR, 1988). Eredményeink képviselik az első fontos lépést afelé a kísérleti megközelítés felé, mely azt vizsgálja, hogy miért és hogyan befolyásolja az érzelem a szóbeli kommunikációs stratégiákat.

Természetesen azt már régóta gyanították, hogy a különböző interperszonális viselkedésekre hatással van az érzelmi állapot (ClORE, SCHWARZ, CONWAY, 1994; WEARY, MARSH, McCORMICK, 1994). Számos kutatásban azt találták, hogy a vidám emberek általában kreatívabbak, nagylelkúbbek, magabiztosabbak és segítőkészebbek, míg a rossz hangulat inkább eredményez negatív, lassú és óvatos reakciókat egy társas helyzetben (BerkowitZ, 1993; Clark, IsEn, 1982; Fiedler, 1991; FORGAS, 1995a, 1998a; SCHWARZ, BLESS, 1991). A nemrég megalkotott, többszörös feldolgozást feltételező Érzelem-befolyás modell (AIM) szerint a hangulati állapot társas viselkedésre gyakorolt hatása nagyban függ attól, hogy egy adott szituációban milyen információfeldolgozási stratégiát alkalmazunk (FIEDLER, 1991; FORGAS, 1995b; MARTIN, 1986). A modell négyféle feldolgozási stratégiát különböztet meg két szempont alapján, melyek: az információkeresési stratégiák nyitottsága (nyílt vagy célirányos keresés) és teljessége (teljes vagy részleges keresés). Az érzelem általában nincs hatással az igen közvetlen vagy csonka stratégiákra, mint amilyen az egy már megtörtént reakcióhoz való közvetlen hozzáférés és a motivált feldolgozás. Ezzel szemben azoknál a feladatoknál, melyek bizonyos fokú folyamatos, részletes feldolgozást igényelnek (mint esetünkben a kérések megfogalmazása), igen valószínű, hogy az érzelembevésődési mechanizmusok által befolyásolt információ hat a feldolgozás végeredményére. Ezt az elképzelést különösen jól igazolta a Második vizsgálat, amiben a hangulati hatás erősebb volt a bonyolultabb társas helyzetekben, valamint a Harmadik és a Negyedik vizsgálat, ahol a hangulat hatása jobban befolyásolta a szokatlan és udvariatlan kérések megítélését, mint a megszokott és udvarias kérésekét (GIBBS, 1983). Azt, hogy a feldolgozási stílusnak 
kritikus szerepe van a hangulati hatások közvetítésében, jól bizonyította a Negyedik vizsgálat, ahol a legszokatlanabb kérések felidézése volt a legpontosabb, mivel ezeket nagy valószínűséggel egyénileg dolgozták fel (5. ábra). Hasonló eredményekre jutott a Hatodik vizsgálat is, melyben megint csak a legszokatlanabb kérések felidézése bizonyult a legpontosabbnak, mivel ezeket is nagy valószínűséggel egyénileg dolgozták fel. Ezek az eredmények összhangban vannak az Érzelem-befolyás modellel (AIM), mely szerint a gondolkodásra, az ítéletekre és a viselkedésre az érzelem befolyásoló hatása nem egységes, hanem azok a feldolgozási stratégiák közvetítik, melyeket a feladat jellemzői váltanak ki.

Talán más magyarázatok is megállják itt a helyüket. Például Schwarz és Bless kognitív ráhangolás (cognitíve tuning) modellje szerint a negatív hangulati állapot olyan információt közvetít számunkra, mely szerint alaposabb és éberebb feldolgozási stratégiára van szükség, ami kifinomultabb - és így udvariasabb - kérésekhez vezet. Bár lehet, hogy egy ilyen folyamat hozzájárult az általunk talált hangulati hatások megjelenéséhez, az kevésbé valószínű, hogy a kognitív ráhangolódás felelős a Második, Harmadik és Negyedik vizsgálatban bemutatott interaktív hangulati hatás megjelenéséért. Egy másik lehetőség, hogy a kísérleti személyek kérésük megfogalmazásánál közvetlenül felhasználták hangulati állapotukat a „mit érzek ezzel kapcsolatban?" heurisztika alapján (SCHWARZ, CLORE, 1983). Ezzel a magyarázattal két probléma van. Először is, mivel a kérés önmagában véve nem egy külön válaszkategória, nem egyértelmű az, hogy a jó vagy a rossz hangulati hatás miként kapcsolódhat közvetlenül az udvarias vagy a kevésbé udvarias kérések előnyben részesítéséhez. Valójában az a tény, hogy a jó hangulat barátságtalan és kevésbé udvarias kérésekhez vezet, arra enged következtetni, hogy a hangulatnak általános, közvetett hatása van arra, ahogyan az emberek értelmezik a kérés kontextusát; tehát nem közvetlenül hat az udvariasnak vagy udvariatlannak vélt kérési formák megfogalmazására. Továbbá a Negyedik vizsgálat eredményei azt mutatják, hogy a nagyobb hangulati hatás összefügg azzal, hogy a mélyebben feldolgozott információt jobban tudjuk előhívni; ami ellentmond az „Érzelem mint információ" modell szerinti egyszerű, heurisztikus feldolgozásnak. Összességében úgy tűnik, hogy az érzelem befolyásoló hatásának törvényszerűségeit az Érzelembefolyás modell (AIM) írja le a legjobban, és ezen belül is az érzelembevésődési mechanizmus elmélete.

Gyakorlati megfontolások. Azok a fajta stratégiai szóbeli üzenetek, melyeket itt megvizsgáltunk, a gyakorlati életben is fontos szerepet játszanak. A nyelv a társas viselkedés elsődleges közvetítőeszköze, és kritikus szerepe van céljaink elérésénél, ezen túl lehetővé teszi a társas viselkedések összehangolását. Bár a nyelvhasználatot befolyásoló kifinomult pragmatikai szabályok mủködését nagyszámú tanulmány vizsgálja (HERRMANN, 1983; VAN DIJK, 1985), még mindig keveset tudunk azokról a pszichológiai változókról, melyek szerepet játszanak a kérések megfogalmazásánál. Kísérleteinkkel megpróbáltuk a gyakorlatban megvizsgálni, hogy milyen hatással van a hangulat a társas kognícióra a nyelvhasználat és a személyközi viselkedés terén. Be tudtuk bizonyítani, hogy az aktuális hangulati állapot igenis fontos szerepet játszik a kérések megfogalmazásában. 
Mivel a kérések stratégiai szempontból fontosak, az itt bemutatott jelenségek - a hangulat szóbeli kommunikációra gyakorolt számottevő befolyásoló hatása komoly gyakorlati jelentőséggel bírnak. A rossz hangulatban megfogalmazott, túlságosan udvarias kérések csökkenthetik az ilyen üzenetek hatékonyságát, ez negatív személyközi tapasztalatokhoz vezethet, melyekkel a szomorú emberek gyakran szembesülnek (OTTAVIANI, BECK, 1988; WEARY, MARSH, McCORMICK, 1994). Ezek az eredmények igen hasznosak lehetnek a depresszióval összefüggésbe hozható kommunikációs problémák megértéséhez. A szociális készségek fejlesztésénél is célszerủ, ha nagyobb figyelmet fordítanak arra, hogy a hangulatnak milyen hatása lehet a hatékony szóbeli kommunikációs stratégiákra. Általában véve eredményeink rávilágítanak arra, hogy a hangulatnak milyen fontos gyakorlati hatása van társas viselkedésünkre, mind magánéletünkben, mind munkánk során.

Korlátok és távlatok. Eredményeinknek van néhány nyilvánvaló korlátja. A munkánk kiindulópontjául szolgáló többszempontos feldolgozási modell szerint, a hangulati hatást a személy által használt feldolgozási stratégia közvetíti; másfelól azt, hogy milyen feldolgozási stratégiát választunk, számos külső és belső tényező befolyásolja (FORGAS, 1995a; 2000, in press). Nyilvánvalóan jelentős szerepe lehet a további tanulmányoknak abban, hogy részleteiben vizsgálják meg azt, hogy a kommunikátor által választott feldolgozási stratégia szempontjából milyen szerepe van a különböző gyakorlati változóknak, melyek közvetítik a hangulat szóbeli üzenetekre gyakorolt hatását. Az itt bemutatott kísérletekben a kísérleti személyeket többé-kevésbé komplex és bonyolult társas helyzeteknek tettük ki, és az eredmények alátámasztják azt az elméletet, miszerint a helyzet nehézsége, valamint a feldolgozási stratégiák közvetítik a hangulati hatásokat. Érdekes lenne azonban további kísérletekben közelebbről megvizsgálni a feldolgozási stratégiákat, például úgy, hogy mérik a feldolgozás időtartamát, mialatt a vidám vagy szomorú kísérleti személyek közvetlen vagy közvetett kéréseket fogalmaznak meg. Ilyen eljárást már sikeresen alkalmaztak számos korábbi vizsgálatban, melyekben azt tanulmányozták, hogy a hangulatnak milyen hatása van az emlékezetre és az ítéletalkotásra. Az eredmények azt mutatják, hogy a feldolgozási idő fontos szerepet játszik a hangulati hatás közvetítésében (BOWER, FORGAS, in press; FORGAS, 1994, 1995b; FORGAS, BOWER, 1987).

Fontos még szólnunk eredményeink külső validitásának kérdéséről, ami különös jelentőséggel bír a szóbeli kommunikáció jelenségét vizsgáló tanulmányok esetében. Az első három kísérletben feltételezett helyzetekkel dolgoztunk. Annak ellenére, hogy eredményeink konzisztensek voltak, fontos azt is bemutatni, hogy a hangulati hatás valós szituációkban is jelen van. Az utolsó három vizsgálat eredményei jól álcázott, valós terepkísérletekből származnak. Ezen vizsgálatok eredményei bizonyítékként szolgálnak arra, hogy a hangulat jelentős szerepet játszik a természetes körülmények közt lezajló beszélgetések esetén is. Nyilvánvaló gyakorlati haszna lenne azonban annak, ha demonstrálnánk, hogy a való életben milyen hatással van a hangulat a nyelvhasználatra.

A mindennapi társalgás folyamán a szóbeli üzenetek megfogalmazása és az azokra való reagálás igen bonyolult kognitív feladat lehet, mely kifinomult követ- 
keztetéseket igényel mind a partnerről, mind a helyzetről. Ezekhez a következtetésekhez szükség van ahhoz, hogy a beszélő azonnal hozzáférhessen a memóriájában tárolt múltbeli interakciós események emlékképeihez. Az elmúlt években jól leírták a nyelvhasználatot irányító kifinomult pragmatikai szabályokat, azonban még mindig túl keveset tudunk arról, hogy az érzelem miként befolyásolja azokat a bonyolult folyamatokat, melyek meghatározzák azt, hogy milyen szavakkal fogalmazzuk meg üzeneteinket. Az érzelmek és a szociális kogníció terén folytatott újabb vizsgálatokra alapozva (BOWER, 1991; FIEDLER, 1988; 1991; FORGAS, 1992a; MAYER, 1986; SAlOveY, Birnbaum, 1989) eredményeink arra engednek következtetni, hogy a jó és a rossz hangulatnak jelentős hatása van arra, ahogy a stratégiai szóbeli üzeneteinket megfogalmazzuk. Ez a hatás attól függ, hogy milyen információfeldolgozó eljárást használunk. Úgy tűnik, hogy a jó hangulat közvetlenebb kérésekre sarkall, mivel a kommunikátor optimistábban ítéli meg üzenete sikerességének esélyeit. A rossz hangulat azonban pesszimistább elvárásokhoz vezet, ami óvatosabb, udvariasabb és körültekintőbb kommunikációs stratégiák használatát eredményezi. A mostanában kifejlesztett többszörös feldolgozási szemlélet (FIEDLER, 1991; FORGAS, 1995a) különösen ígéretes a kifinomult, feldolgozásfüggő hatások megértésénél. Az érzelem és a szóbeli kommunikáció kapcsolatát vizsgáló további kutatások jelentős elméleti és gyakorlati érdeklődésre tarthatnak számot, mivel ezek hozzájárulnak ahhoz, hogy jobban megértsük a hangulat kognícióra gyakorolt hatását, valamint az interperszonális viselkedés dinamikáját.

\section{IRODALOM}

Argyle, M. (1991) A critique of cognitive approaches to social judgment and social behavior. In Forgas, J. P. (ed.) Emotion and social judgments. 161-181. Pergamon, Oxford

Axia, G., BARONi, M. R. (1985) Linguistic politeness at different age levels. Child Development, 56, 918-927.

Bavelas, J. (1985) A situational theory of disqualification: Using language to leave the field'. In Forgas, J. P. (ed.) Language and Social Situations. 189-213. Springer, New York

Berkowitz, L. (1993) Towards a general theory of anger and emotional aggression. In Srull, T. K., Wyer, R. S. (eds) Advances in social cognition. Vol. 5. 1-46. Erlbaum, Hillsdale

Blum-Kulka, S., Danet, B., Gershon, R. (1985) The language of requesting in Israeli society. In Forgas, J. P. (ed.) Language and Social Situations. 113-141. Springer, New York

Bower, G. H. (1991) Mood congruity of social judgments. In Forgas, J. P. (ed.) Emotion and social judgments. 31-55. Pergamon Press, Oxford

Bower, G. H., Forgas, J. P. (in press) Mood and Social Memory. In Forgas, J. P. (ed.) The Handbook of Affect and Social Cognition. Erlbaum, Mahwah

Brown, P., Levinson, S. (1987) Politeness: Some universals in language use. Cambridge University Press, Cambridge 
Brewer, M. (1988) A dual-process model of impression formation. In Srull, T. K., Wyer, R. S. (eds) Advances in Social Cognition. Vol. 1. 1-36. Erlbaum, Hillsdale

Chaiken, S. (1980) Heuristic vs. systematic information processing and the use of source vs. message cues in persuasion. Journal of Personality and Social Psychology, 39, 752-766.

Clark, H. H., Schunk, D. H. (1980) Polite responses to polite requests. Cognition, 8, $111-$ 143.

Clark, M. S., IsEn, A. M. (1982) Towards understanding the relationship between feeling states and social behavior. In Hastorf, A. H., Isen, A. M. (eds) Cognitive social psychology. 76-108. Elsevier-North Holland, New York

Clore, G. L., Byrne, D. (1974) The reinforcement model of attraction. In Huston, T. L. (ed.) Foundations of interpersonal attraction. 143-170. Academic Press, New York

Clore, G. L., Gasper, K., Garvin, E. (in press) Affect as Information. In Forgas, J. P. (ed.) The Handbook of Affect and Social Cognition. Erlbaum, Mahwah

Clore, G. L., Schwarz, N., Conway, M. (1994) Affective causes and consequences of social information processing. In Wyer, R. S., Srull T. K. (eds) Handbook of social cognition. 2nd Ed. Erlbaum, New Jersey

Feshbach, S., Singer, R. D. (1957) The effects of fear arousal and suppression of fear upon social perception. Journal of Abnormal and Social Psychology, 55, 283-288.

FiEDLER, K. (1988) Emotional mood, cognitive style, and behavior regulation. In Fiedler, K., Forgas, J. (eds) Affect, Cognition and Social Behavior. C. J. Hogrefe, Toronto

Fiedler, K. (1990) Mood dependent selectivity in social cognition. In Stroebe, W., Hewstone, M. (eds) European Review of Social Psychology. Vol. 1. 1-32. Wiley, Chichester

FiedLer, K. (1991) On the task, the measures, and the mood in research on affect and social cognition. In Forgas, J. P. (ed.) Emotion and social judgments. 83-107. Pergamon, Oxford

Forgas, J. P. (1983) Language, goals and situations. Journal of Language and Social Psychology, 2, 267-293.

Forgas, J. P. (ed.) (1985) Language and Social situations. Springer, New York

ForGas, J. P. (1992a) Affect in social judgments and decisions: A multi-process model. In Zanna, M. (ed.) Advances in Experimental Social Psychology. Vol. 25. 227-275. Academic Press, New York

Forgas, J. P. (1992b) On mood and peculiar people: Affect and person typicality in impression formation. Journal of Personality and Social Psychology, 63, 863-875.

Forgas, J. P. (1994) Sad and guilty? Affective influences on the explanation of conflict episodes. Journal of Personality and Social Psychology, 66, 56-68.

Forgas, J. P. (1995a) Mood and judgment: The Affect Infusion Model (AIM). Psychological Bulletin, 116, 39-66.

Forgas, J. P. (1995b) Strange couples: Mood effects on judgments and memory about prototypical and atypical targets. Personality and Social Psychology Bulletin, 21, 747-765.

ForGas, J. P. (1998a) On feeling good and getting your way: Mood effects on negotiation strategies and outcomes. Journal of Personality and Social Psychology, 74, 565-577.

Forgas, J. P. (1998b) Asking nicely? Mood effects on responding to more or less polite requests. Personality and Social Psychology Bulletin, 24, 173-185.

Forgas, J. P. (1998c) Happy and Mistaken? Mood effects on the fundamental attribution error. Journal of Personality and Social Psychology, 75, 318-331. 
ForGas, J. P. (1999a) On feeling good and being rude: Affective influences on language use and request formulations. Journal of Personality and Social Psychology, 76, 928-939.

ForGAS, J.P. (1999b) Feeling and speaking: Mood effects on verbal communication strategies. Personality and Social Psychology Bulletin, 25, 850-863.

ForGaS, J. P. (ed.) (2000) Feeling and thinking: the role of affect in social cognition. Cambridge University Press, New York

Forgas, J. P. (ed.) (in press) The Handbook of Affect and Social Cognition. Erlbaum, Mahwah

ForGas, J. P., BowER, G. H. (1987) Mood effects on person perception judgements. Journal of Personality and Social Psychology, 53, 53-60.

Forgas, J. P., Bower, G. H., KRANTZ, S. (1984) The influence of mood on perceptions of social interactions. Journal of Experimental Social Psychology, 20, 497-513.

GibBS, R. (1983) Do people always process the literal meaning of indirect requests? Journal of Experimental Psychology: Learning, Memory and Cognition, 9, 524-533.

Gibbs, R. (1985) Situational conventions and requests. In Forgas, J. P. (ed.) Language and social situations. 97-113. Springer, New York

Goffman, E. (1984) Keretelemzés. In Goffman, E. (szerk.) A hétköznapi élet szociálpszichológiája. 143-174. Gondolat kiadó, Budapest

GRICE, H. P. (1988) A társalgás logikája. In Pléh Cs., Síklaki I., Terestyéni T. (szerk.) Nyelv, kommunikáció, cselekvés. 192-216. Tankönyvkiadó, Budapest

HARRE, R. (1985) Situational rhetoric and self-presentation. In Forgas, J. P. (ed.) Language and Social Situations. 175-189. Springer, New York

Herrmann, T. (1983) Speech and situation. Springer, New York

IsEN, A. (1987) Positive affect, cognitive processes, and social behavior. In Berkowitz, L. (ed.) Advances in Experimental Social Psychology. Vol. 20. 203-253. Academic Press, New York

JONES, E. E. (1964) Ingratiation. Appleton-Century-Crofts, New York

Jordan, J. M., Roloff, M. E. (1990) Acquiring assistance from others: The effect of indirect requests and relation intimacy on verbal compliance. Human Communication Research, 16, 519-555.

Kitayama, S., Burnstein, E. (1988) Automaticity in conversations: A re-examination of the mindlessness hypothesis. Journal of Personality and Social Psychology, 54, 219-224.

Kruglanski, A. W. (1989) Lay epistemics and human knowledge: Cognitive and motivational bases. Plenum, New York

Langer, E. J. Blank, A., Chanowitz, B. (1978) The mindlessness of ostensibly thoughtful action: The role of 'placebic' information in interpersonal interaction. Journal of Personality and Social Psychology, 36, 635-642.

ManN, L. (1992) Stress, affect and risk taking. In Yates, J. F. (ed.) Risk-taking behavior. 202230. Wiley, Chichester

MARTIN, L. L. (1986) Set/reset: Use and disuse of concepts in impression formation. Journal of Personality and Social Psychology, 51, 493-504.

Martin, L. L., Ward, D. W., Achee, J. W., Wyer, R. S. (1993) Mood as input: People have to interpret the motivational implications of their moods. Journal of Personality and Social Psychology, 64, 317-326.

MaYer, J. D. (1986) How mood influences cognition. In Sharkey, N. E. (ed.) Advances in cognitive science. Vol. 1. 290-314. Ellis Horwood, Chichester 
Mayer, J., Hanson, E. (1995) Mood-congruent judgment over time. Personality and Social Psychology Bulletin, 21, 237-244.

MEAD, G. H. (1973) A pszichikum, az én és a társadalom. Gondolat kiadó, Budapest

Milberg, S., Clark, M. S. (1988) Moods and compliance. British Journal of Social Psychology, 27, 79-90.

Ottaviani, R., Beck, A. T. (1988) Cognitive theory of depression. In Fiedler, K., Forgas, J. P. (eds) Affect, cognition and social behavior. 209-219. Hogrefe, Toronto

Petty, R. E., Gleicher, F., Baker, S. (1991) Multiple roles for affect in persuasion. In Forgas, J. P. (ed.) Emotion and social judgments. 181-200. Pergamon, Oxford

Petty, R. E., Schumann, D., Richman, S., Strathman, A. (1993) Positive mood and persuasion: Different roles for affect under high and low elaboration conditions. Journal of Personality and Social Psychology, 64, 5-20.

Salovey, P., Birnbaum, D. (1989) Influence of mood on health-related cognitions. Journal of Personality and Social Psychology, 57, 539-551.

Salovey, P., Mayer, J. D. (1990) Emotional intelligence. Imagination, Cognition and Personality, 9, 185-211.

Schwarz, N., Bless, H. (1991) Happy and mindless, but sad and smart? The impact of affective states on analytic reasoning. In Forgas, J. P. (ed.) Emotion and social judgments. 55-71. Pergamon Press, Oxford

Schwarz, N., Clore, G. L. (1983) Mood, misattribution and judgments of well-being: Informative and directive functions of affective states. Journal of Personality and Social Psychology, 45, 513-523.

SEDIKIDES, C. (1992) Changes in the valence of the self as a function of mood. In Clark, M. (ed.) Emotion and social behavior. 42-67. Sage, Beverly Hills

SEDikides, C. (1995) Central and peripheral self-conceptions are differentially influenced by mood: Test of the differential sensitivity hypothesis. Journal of Personality and Social psychology, 69, 759-777.

SINCLAIR, R. C. (1988) Mood, categorization breadth and performance appraisal: The effects of order of information acquisition and affective state on halo, accuracy, information retrieval, and evaluations. Organizational Behavior and Human Decision Processes, 42, 22-46.

Sinclair, R. C., Mark, M. M. (1992) The influence of mood state on judgment and action. In Martin, L. L., Tesser, A. (eds) The construction of social judgments. 165-193. Erlbaum, Hillsdale, N. J.

VAN DiJK, T. (1985) Cognitive situation models is discourse production. In Forgas, J. P. (ed.) Language and Social Situations. Springer, New York

Weary, G., Marsh, K. L., McCormick, L. (1994) Depression and social comparison motives. European Journal of Social Psychology, 24, 117-130.

Wheeler, L., Miyake, L. (1992) Social comparison in everyday life. Journal of Personality and Social Psychology, 62, 760-774.

Vigotszkij, L. Sz. (1967) Gondolkodás és beszéd. Akadémiai Kiadó, Budapest 


\title{
AFFECT AND STRATEGIC COMMUNICATION: THE EFFECTS OF MOOD ON THE PRODUCTION AND INTERPRETATION OF VERBAL REQUESTS
}

\author{
FORGÁCS, JÓZSEF
}

Everyday language use presents us with complex strategic choices. What is the role of mood in the way we use and respond to verbal messages, such as requests? Based on the Affect Infusion Model (AIM; Forgas, 1995a), this paper reviews several recent experiments that predicted and found that negative moods induce more polite, and positive moods induce less polite requesting strategies, and that these mood effects are amplified in contexts that call for more elaborate processing. In Study 1 sad participants preferred more polite requests than did happy people, and Study 2 found that situational difficulty accentuated the effects of mood. Study 3 showed that mood effects occur across a variety of request scenarios, and are most pronounced for unconventional, impolite requests. In an unobtrusive procedure, Study 4 established that sad subjects were more polite as well as more hesitant when naturally producing requests in a realistic conversation, and their memory was also best for more extensively processed, unconventional requests. In Study 5 sad mood led to the more negative evaluation, and reduced compliance with naturalistic requests, and this effect was amplified for direct, unconventional requests. Study 6 replicated this finding and also showed that memory was better for unconventional, impolite requests, consistent with the predicted more substantive processing of these messages. These results are consistent with the AIM, and are discussed in terms of the cognitive processing strategies that mediate mood effects on complex verbal moves such as requests. The implications of the findings for strategic interpersonal behavior, and for contemporary theories of affect and cognition are considered.

Everyday social life largely consists of verbal communication. We use verbal messages to establish a shared understanding of the world, to construct a coherent sense of the self, and to achieve our interpersonal goals (MEAD, 1934; VYGOTSKY, 1962). Dealing with requests in particular is a common, yet strategically highly demanding interpersonal task. Despite the ubiquity of verbal messages in social interaction, we still know very little about how a speaker's temporary mood influences complex verbal moves, such as requests. This paper reviews a series of recent studies that seek to extend recent research on the effects of mood on social cognition and judgments (BOWER, 1991; CLORE, SCHWARZ, CONWAY, 1994; FIEDLER, 1991; FORGAS, 1995b; 2000) to the domain of interpersonal behavior, by demonstrating that temporary mood states also significantly influence strategic verbal communication, such as requesting. Drawing on past research on requesting (BLUM-KULKA, DANET, GERSHON, 1985; GIBBS, 1983, 1985), as well as recent affect-cognition theorizing (FIEDLER, 1991; FORGAS, 1995a), these studies seek to show that temporary moods exert a significant informational bias both on request choices, and on reactions to naturalistic requests.

Requesting is a common, yet strategically important verbal task. Many everyday requests readily comply with conventional norms of politeness, and can be produced, and responded to in an automatic, almost mindless fashion (GIBBS, 1983; LANGER, BLANK, CHANOWITZ, 1978). At other times, however, dealing with requests requires more elaborate processing in order to make sense of the conflicting requirements inherent in a requesting situation (BAVELAS, 1985). People often seek to find the optimum request formulation that is sufficiently direct to maximise the likelihood of compliance, yet not so direct as to violate social norms of politeness and thus give offence (FORGAS, 1985; GIBBS, 1983; JORDAN, ROLOFF, 1990). In other words, in more problematic situations speakers need to employ more substantive processing strategies in order to carefully estimate the 'felicity conditions' for their requests, such as the likelihood and costs of compliance and rejection associated with more or less direct verbal forms. Recent research suggests that mood is most likely to have an influence on tasks that require such open, substantive processing strategies (FIEDLER, 1991; FORGAS, 1994; 1995b; 1998a; b; 1999a; b; SEDIKIDES, 1995).

Key words: sociolingvistics, social psychology of language, affect infusion, emotional influence, requests, mood, politeness 